\title{
A SUMMARY OF RHEOLOGY DATA FOR SB3 AND SB2/3 BLEND SIMULANT SAVANNAH RIVER SITE WASTES (U)
}

Authors

D. C. Koopman

E. K. Hansen

March 2004

Immoblization Technology Section

Savannah River Technology Center

Savannah River Technology Center

Aiken, SC 29808

Prepared for the U.S. Department of Energy Under Contract Number DEAC09-96SR18500

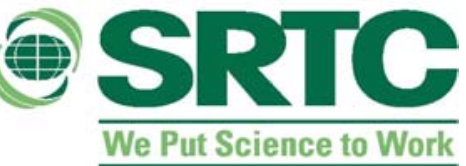


This document was prepared in conjunction with work accomplished under Contract No. DE-AC09-96SR18500 with the U. S. Department of Energy.

\section{DISCLAIMER}

This report was prepared as an account of work sponsored by an agency of the United States Government. Neither the United States Government nor any agency thereof, nor any of their employees, makes any warranty, express or implied, or assumes any legal liability or responsibility for the accuracy, completeness, or usefulness of any information, apparatus, product or process disclosed, or represents that its use would not infringe privately owned rights. Reference herein to any specific commercial product, process or service by trade name, trademark, manufacturer, or otherwise does not necessarily constitute or imply its endorsement, recommendation, or favoring by the United States Government or any agency thereof. The views and opinions of authors expressed herein do not necessarily state or reflect those of the United States Government or any agency thereof.

This report has been reproduced directly from the best available copy.

Available for sale to the public, in paper, from: U.S. Department of Commerce, National Technical Information Service, 5285 Port Royal Road, Springfield, VA 22161, phone: (800) 553-6847, fax: (703) 605-6900

email: orders@ntis.fedworld.gov

online ordering: http://www.ntis.gov/help/index.asp

Available electronically at http://www.osti.gov/bridge

Available for a processing fee to U.S. Department of Energy and its contractors, in paper, from: U.S. Department of Energy, Office of Scientific and Technical Information, P.O. Box 62, Oak Ridge, TN 37831-0062,

phone: (865)576-8401,

fax: (865)576-5728

email: $\underline{\text { reports@ adonis.osti.gov }}$ 
Key Words: Rheology, Sludge,

SRAT, SME, DWPF, Waste,

Simulant

Retention: Permanent

\section{A SUMMARY OF RHEOLOGY DATA FOR SB3 AND SB2/3 BLEND SIMULANT SAVANNAH RIVER SITE WASTES (U)}

Authors

D. C. Koopman

E. K. Hansen

March 2004

Immoblization Technology Section Savannah River Technology Center Savannah River Technology Center Aiken, SC 29808 
This page was intentionally left blank 


\section{EXECUTIVE SUMMARY}

The purpose of this study was to document the rheological measurements made for Sludge Batch 3 (SB3) and the blend of SB3 with Sludge Batch 2 (SB2). These measurements were primarily made on Slurry Mix Evaporator (SME) products, i.e. melter feeds. Some measurements were made on SB2/3 blend Sludge Receipt and Adjustment Tank (SRAT) products. Measurements on radioactive SB3 and SB2/3 samples have been limited to sludge characterization.

SB2/3 measurements studied the impact of changing the SRAT acid addition strategy on the SRAT and SME product rheology. SB2/3 measurements also studied the impact of changing the waste loading target (sludge oxides content in glass) of the SME product. SB3 measurements studied the impact of changes in the wash end point and acid addition strategy on the SME product (melter feed) rheology.

A summary of the significant findings is given below:

$\mathrm{SB} 3$ radioactive sludge and blended SB2/3 radioactive sludge were less viscous than SB2 radioactive sludge. SB2/3 blend sludge is more viscous than SB3 sludge.

SB3 simulant SME product rheology was strongly impacted by changing the noble metal concentrations to more closely match those of the qualification sample. This reduction in noble metals produced a lower $\mathrm{pH}$ product that was also considerably less viscous.

Increased acid addition in the SB2/3 SRAT generally led to less viscous simulant SRAT products. This trend did not persist in the SME products. SME products became more viscous when increased acid was used in the SRAT cycle from $135 \%$ up to $170 \%$ of stoichiometry, then became less viscous as total acid was increased further to $185 \%$. A significant increase in hydrogen generation occurred between $170 \%$ and $185 \%$. The impact of acid addition on SB3 SME products was also variable.

The impact of waste loading changes from $31 \%$ to $35 \%$ to $40 \%$ on SB2/3 simulant SME products led to more viscous melter feeds as waste loading increased at constant wt. $\%$ total solids.

The slurry $\mathrm{pH}$ seemed to be having a significant effect on the rheological variations within a set of similar simulant samples. The most viscous slurry in a set often had an intermediate $\mathrm{pH}$ in the 5-8 range.

Rheological differences were seen as a function of wash endpoint with simulants. The Case $7 \mathrm{~d}$ SB2/3 SME product was more viscous than the less-washed Case 6b SME product. The more-washed SB3 simulant SME products that started at $20,000 \mathrm{mg} / \mathrm{kg}$ sludge nitrite were more viscous than the lesswashed SB3 simulant SME products that started at $27,000 \mathrm{mg} / \mathrm{kg}$ sludge nitrite. 


\section{TABLE OF CONTENTS}

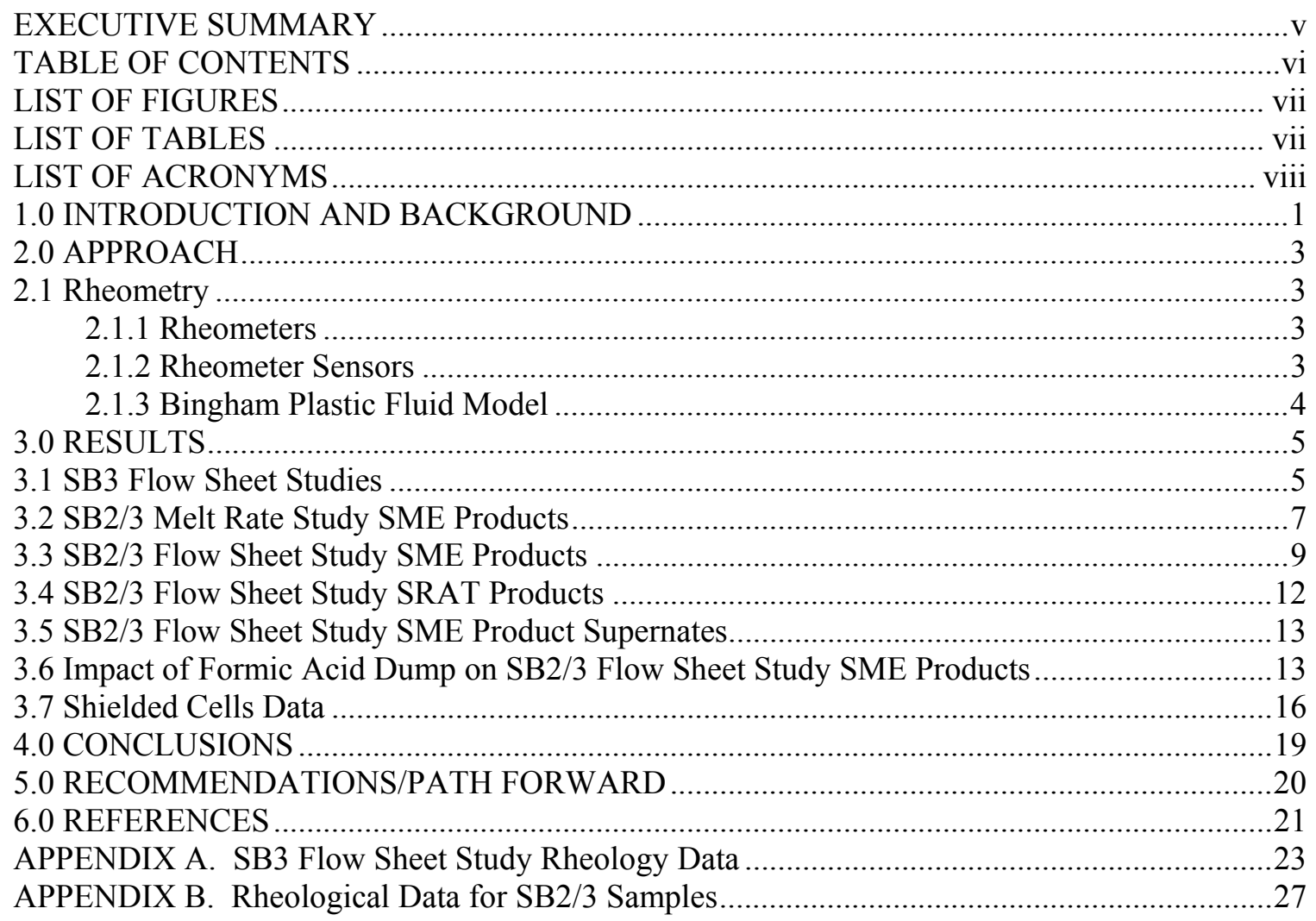




\section{LIST OF FIGURES}

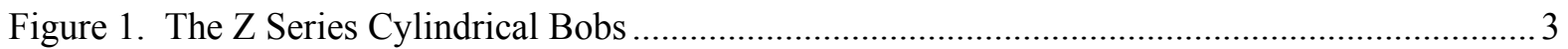

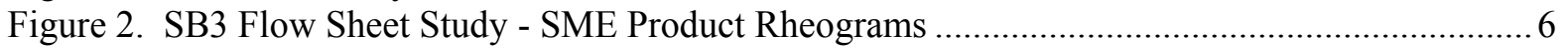

Figure 3. SB2/3 Case 6b SME Product (SMRF Feed) Rheology Data .............................................. 8

Figure 4. SB2/3 SME Product (SMRF Feed) Rheology Data vs. Wash Endpoint.............................. 9

Figure 5. Z38 SB2/3 SME Product Rheology as a Function of Acid Stoichiometry .......................... 10

Figure 6. Z31 SB2/3 SME Product Rheology as a Function of Acid Stoichiometry ......................... 11

Figure 7. First Rheograms of SB2/3 SRAT Products................................................................... 12

Figure 8. Second Rheograms of SB2/3 SRAT Products ................................................................... 13

Figure 9. Impact of Formic Acid Dump on SB2/3 SME Product Rheology ..................................... 14

Figure 10. Impact of Formic Acid Dump on 155\% Acid SME Product .......................................... 15

Figure 11. Impact of Formic Acid Dump on 185\% Acid SME Product ......................................... 16

Figure 12. Rheological Data for SB3 Sludge Used in Qualification Work ...................................... 17

Figure 13. Preliminary Rheological Data for SB2/3 Blended Sludge ............................................ 18

Figure 14. Comparison of the Three Radioactive Sludge Rheograms. ........................................... 18

\section{LIST OF TABLES}

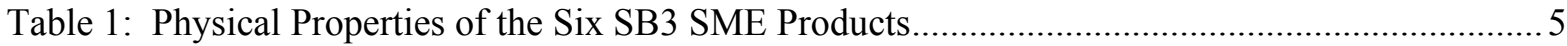

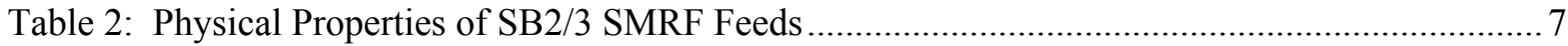

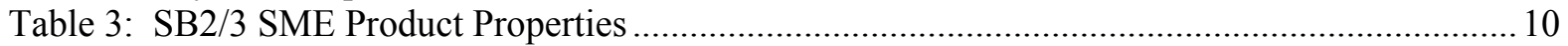

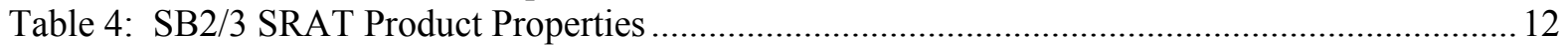




\section{LIST OF ACRONYMS}

$\begin{array}{ll}\text { ACTL } & \text { Aiken County Technical Laboratory } \\ \text { CETL } & \text { Clemson Environmental Technologies Laboratory } \\ \text { DWPF } & \text { Defense Waste Processing Facility } \\ \text { NIST } & \text { National Institute of Standards } \\ \text { SME } & \text { Slurry Mix Evaporator } \\ \text { SRAT } & \text { Sludge Receipt and Adjustment Tank } \\ \text { SB1A } & \text { Sludge Batch 1A (first batch processed in DWPF) } \\ \text { SB1B } & \text { Sludge Batch 1B (second batch processed in DWPF) } \\ \text { SB2 } & \text { Sludge Batch 2 (current batch in DWPF) } \\ \text { SB3 } & \text { Sludge Batch 3 (next batch to be fed to DWPF) } \\ \text { SMRF } & \text { Slurry-fed Melt Rate Furnace } \\ \text { SRS } & \text { Savannah River Site } \\ \text { SRTC } & \text { Savannah River Technology Center } \\ \text { USC } & \text { University of South Carolina - Columbia }\end{array}$




\subsection{INTRODUCTION AND BACKGROUND}

This document summarizes the results of over 60 rheological measurements made on Sludge Receipt and Adjustment Tank (SRAT) and Slurry Mix Evaporator (SME) products during the simulant development work to support Sludge Batch 3 (SB3) and the blend of SB3 with Sludge Batch 2 (SB2). It also discusses preliminary rheological measurements on SB3 and SB2/3 radioactive sludge samples prepared in the Savannah River Technology Center (SRTC) Shielded Cells. SB3 sludge is defined as the material that was prepared in Tank 51 for eventual combination with SB2. This was primarily Tank 7 waste. SB2/3 is defined as the projected composition of SB3 after it has been combined with a large heel of SB2. This also includes contributions from $\mathrm{Am} / \mathrm{Cm}, \mathrm{Pu} / \mathrm{U} / \mathrm{Gd}$, and $\mathrm{Np}$ expected to be incorporated into SB2/3.

SB3 SME products (melter feeds) were produced during 4-L SRAT and SME simulations at the Aiken County Technical Laboratory (ACTL) in 2003. These samples were based on simulant compositions that were adjusted based on the initial analyses of radioactive Tank 7 waste in SRTC and on the projected compositions of the Canyon disposition streams. Several levels of noble metal concentrations and several wash end points were simulated by adjusting the trim chemicals added to the very-washed starting simulant produced at the Clemson Environmental Technologies Laboratory (CETL). These included the baseline case, Case $6 \mathrm{~b}(\sim 26,000-27,000 \mathrm{ppm}$ nitrite), as well as other nitrite levels.

The initial SB2/3 blend SME product simulant was prepared in the 22-L SRAT/SME equipment used to support Slurry-fed Melt Rate Furnace (SMRF) testing. This simulant was based on June 2003 projections for the blend composition of the starting sludge (after 250 canisters from SB2). A slightly revised blend composition for SB2/3 was generated in November 2003 for use in 4-L SRAT/SME studies into the impact of changes in the acid addition strategy on processing. The SB3 portion was generally like Case $6 \mathrm{~b}$. One set of runs targeted the alternate wash case, Case $7 \mathrm{~d}(\sim 18,000 \mathrm{ppm}$ nitrite), with the composition from the June 2003 time frame.

Case $7 \mathrm{~d}$ and Case $6 \mathrm{~b}$ nitrite levels $(18,000-27,000 \mathrm{mg} / \mathrm{kg})$ were above those generally tested prior to the consideration of SB3 and SB2/3. Other supernate species were also proportionately higher than in the past, e.g. hydroxide, nitrate, etc. These higher supernate solids concentrations were due to less washing. This meant that higher wt. \% total solids slurries would need to be fed to the Defense Waste Processing Facility (DWPF) to keep the sludge oxide mass, i.e. the calcined solids mass, per SRAT batch approximately constant.

SB3 radioactive sludge was prepared from a sample of Tank 51. Two additional streams were added to this sample after it was decanted. One stream contained a Pu canyon precipitate (containing Gd and U) intended to simulate a planned transfer from F-Canyon into this sludge batch. The other stream contained a $\mathrm{Np}$ canyon precipitate intended to simulate a planned transfer to Tank 40 following the combination of the contents of Tank 51 with SB2 (in Tank 40). SB2/3 radioactive sludge was prepared by combining the trimmed SB3 radioactive sludge with some of the 2003 sample of SB2 taken from Tank 40. The blend represented $60 \%$ SB3 by mass and 40\% SB2 by mass and assumed a February 2004 blend date. 
WSRC-TR-2004-00116

Revision 0

This page intentionally left blank. 


\subsection{APPROACH}

\subsection{RHEOMETRY}

Rheology is the science of the deformation and flow of matter. Rheometry is the measurement of the deformation and flow of matter.

\subsubsection{Rheometers}

SRTC measured rheological properties of SB2/3 and SB3 simulant slurries using either Haake RS150 or RS600 research grade rheometers. These instruments are located at ACTL. Radioactive slurry measurements were made using a Haake RV30/M5 rheometer. This instrument is located in the SRTC Shielded Cells.

\subsubsection{Rheometer Sensors}

The primary measurement mode for slurry samples has been to use the coaxial cylinder geometry operated in the Searle mode (rotating inner cylinder-fixed outer cylinder). This configuration involves a vertical cylindrical beaker that holds the slurry sample. A solid cylindrical bob is moved into the slurrycontaining beaker along a vertical axis. The sample flows into the annular region between the walls of the bob and the beaker as the two cylinders are brought into the measuring geometry. The bob is spun over a predetermined range of revolutions per minute (ramped up), held at the upper speed, and then decelerated back to a stationary position (ramped down). Beakers and bobs for the RS150 and RS600 are interchangeable. These bobs have designations such as Z41, Z38, and Z31 in order of decreasing diameter (Figure 1).

Figure 1. The Z Series Cylindrical Bobs

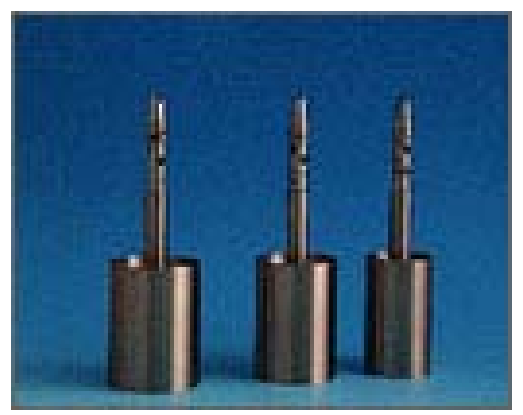

The $Z$ series bobs are made of titanium instead of stainless steel (less mass). This increases their sensitivity and accuracy at small shear rates. Z41 bobs were used for SRAT product rheology measurements. Z38 and Z31 bobs were used for SME product rheology measurements. The Z38 bob is the traditional choice for SME products, but the Z31 bob seemed to give improved response for the SB2/3 SME products produced in the acid stoichiometry study. For the simulant supernate rheology measurement, a $60-\mathrm{mm}$ diameter, $0.5^{\circ}$ cone-and-plate geometry was used, due to sample size requirements. Radioactive sludge measurements were made using the MV1 bob. The MV1 bob is generally similar to the Z41 bob with approximately the same ratio of inner to outer radii of the bob and beaker. MV1 is slightly longer than Z41, $60 \mathrm{~mm}$ vs. $55 \mathrm{~mm}$, and is made of stainless steel.

Ramping of the cylindrical bob speed was done as a linear function of the time, i.e. if the shear rate was to be ramped from $0 / \mathrm{s}$ to $500 / \mathrm{s}$ over five minutes, then the shear rate was $100 / \mathrm{s}$ after one minute, $200 / \mathrm{s}$ after 
two minutes, etc. SB2/3 and SB3 rheology measurements used five minutes for both the up flow curve ramp time and for the down flow curve ramp durations. Different ramp end points were selected based on the choice of the cylindrical bob and the nature of the sample. The rheometers measure the torque and angular speed of the rotating bob. The torque is converted to shear stress using a mathematical model. The angular speed is converted to shear rate using a mathematical model that assumes the fluid is Newtonian in behavior.

The measuring beaker was surrounded by a circulating water jacket. The temperature of the jacket fluid was controlled to hold the samples at $25^{\circ} \mathrm{C}$. The rheometers are functionally verified operational using National Institute of Standards (NIST) traceable oil standards prior to measurements.

\subsubsection{Bingham Plastic Fluid Model}

Rheometric data are often reduced using a rheological model, or relationship between shear stress and shear rate. One of the simplest of these is the Bingham Plastic fluid model. This model is a two parameter relationship between the shear stress and the shear rate (Newtonian fluids have a one parameter relationship through viscosity):

$$
\text { shear stress }=\text { yield stress }+ \text { consistency } * \text { shear rate }
$$

The yield stress and consistency are the two parameters. They are constants for a given sample. This model reduces to the Newtonian fluid when the yield stress is zero. The consistency then becomes equivalent to the Newtonian fluid viscosity. When the yield stress is not zero, however, the consistency is no longer analogous to the viscosity. Instead, the physically analogous quantity to Newtonian viscosity, sometimes referred to as the apparent viscosity, is given by the ratio of the shear stress to the shear rate:

$$
\frac{\text { shear stress }}{\text { shear rate }}=\text { consistency }+\frac{\text { yield } \text { stress }}{\text { shear rate }}=\text { apparent viscosity }
$$

The apparent viscosity of a Bingham plastic fluid decreases with increasing shear rate per the equation above. This type of fluid behavior is called shear thinning. Savannah River Site (SRS) waste slurries typically behave like shear thinning fluids. The apparent viscosity goes to infinity as the shear rate goes to zero. This is a common feature of all models that have a yield stress. The yield stress and the consistency are assumed to be independent of time under shear. Not all product slurries studied during $\mathrm{SB} 2 / 3$ and SB3 simulations possessed this characteristic.

An issue that can arise in making rheological measurements is a departure from laminar flow. This occurs in the form of Taylor vortices when using the concentric cylinder geometry with a rotated inner cylinder. Data should be rejected when the shear stress falls below a critical value given by:

$$
\text { shear stress } \text { critical }=\frac{\text { density }^{*}\left(R_{o}-R_{i}\right)^{2.5}}{41.3 * R_{i}^{0.5}} *(\text { shear rate })
$$

$R_{o}$ and $R_{i}$ are the outer and inner radii of the annular gap respectively. Some of the graphs given in this report will show this relationship in addition to the raw rheological data. 


\subsection{RESULTS}

This section summarizes the principle rheological data generated in support of SB3 and SB2/3 activities.

\subsection{SB3 Flow Sheet Studies}

Eleven SRAT simulations were performed following the chemical analysis of Tank 7 samples in the Shielded Cells. Two of these had no SME cycle, while a third had an abbreviated SME cycle. Product slurry samples from six of the eight simulations with complete SME cycles were analyzed using the rheometers at ACTL. (Further details on all eleven runs can be found in WSRC-TR-2003-00283 and WSRC-TR-2003-00422.) The simulation targets of the individual SME product samples that were analyzed for rheometric properties are summarized below:

- SB3A-13; the final run with high noble metals; based on Case 7 wash endpoint (washing performed after $\mathrm{Pu}$ addition) of $21,000 \mathrm{ppm}$ nitrite and $138 \%$ of stoichiometry with a targeted waste loading of about $32 \%$ sludge oxides in glass.

- SB3A-16; a wash endpoint of $27,000 \mathrm{ppm}$ nitrite and $158 \%$ of stoichiometry with a targeted waste loading of about $37 \%$ sludge oxides in glass.

- SB3A-17; a wash endpoint of $21,000 \mathrm{ppm}$ nitrite and $126 \%$ of stoichiometry with a targeted waste loading of about $37 \%$ sludge oxides in glass.

- SB3A-18; a wash endpoint of 21,000 ppm nitrite and $152 \%$ of stoichiometry with a targeted waste loading of about $38 \%$ sludge oxides in glass.

- SB3A-19; the nominal wash endpoint of $27,000 \mathrm{ppm}$ nitrite, and $120 \%$ of stoichiometry with a targeted waste loading of about $37 \%$ sludge oxides in glass.

- SB3A-20; the nominal wash endpoint of $27,000 \mathrm{ppm}$ nitrite, and $155 \%$ of stoichiometry with a targeted waste loading of about $38 \%$ sludge oxides in glass.

The $\%$ acid stoichiometries given above are based on the analytical results of the SRAT receipt sample pulled from the vessel after all trimming was completed. They are accurate to within about $\pm 5 \%$. SB3A17 and 18 formed a pair of matched runs with two different acid addition strategies, as did SB3A-19 and 20. SB3A-13 was different for many reasons relative to the other five runs, for example it had much higher noble metal concentrations and significantly lower waste loading. Frit 202 was used throughout.

Figure 2 shows the initial portion of the up ramp flow curve for each of the six samples. Rheological reproducibility was high for five of the six samples, meaning that the first and second flow curve were nearly identical. SB3A-16 was analyzed five times, after which three of the five flow curves were nearly identical. The other two flow curves were rejected. One of the set of three similar flow curves was included in Figure 2. Full flow curves are given in Appendix A. Physical properties of the six SME products are given in Table 1.

Table 1: Physical Properties of the Six SB3 SME Products

\begin{tabular}{|l|c|c|c|c|c|c|}
\hline & SB3A-13 & SB3A-16 & SB3A-17 & SB3A-18 & SB3A-19 & SB3A-20 \\
\hline Wt. \% Total Solids & 49.9 & 50.3 & 49.0 & 50.7 & 53.8 & 51.8 \\
\hline Wt. \% Insoluble Solids & 39.3 & 35.9 & 36.4 & 37.3 & 38.7 & 36.3 \\
\hline Density (g/ml) & 1.46 & 1.43 & 1.49 & 1.55 & 1.54 & 1.54 \\
\hline pH & 8.31 & 5.59 & 7.33 & 6.51 & 7.61 & 6.98 \\
\hline
\end{tabular}


Figure 2. SB3 Flow Sheet Study - SME Product Rheograms

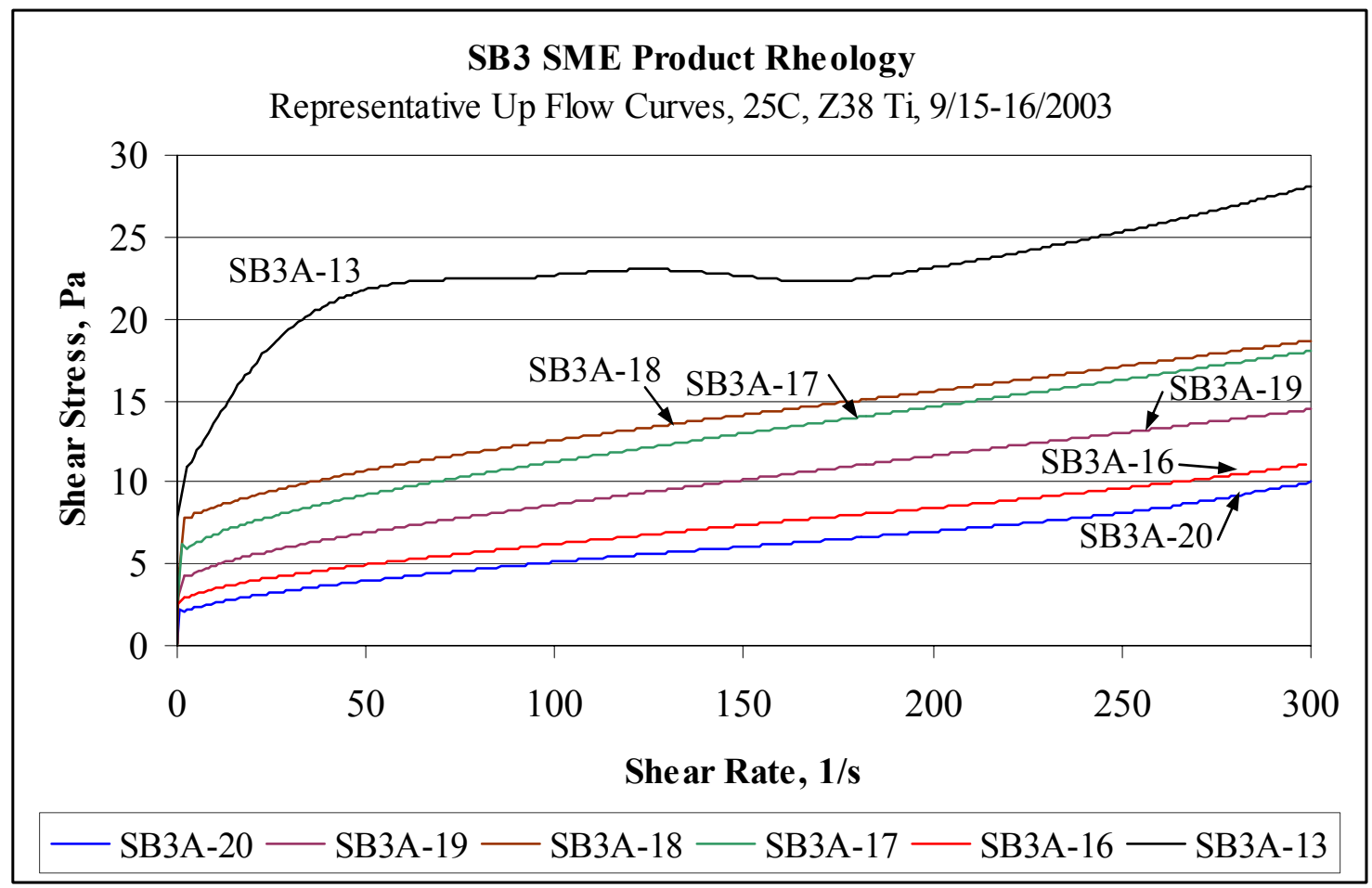

The following observations were made based on the results in Table 1 and Figure 2:

- The more washed pair, SB3A-17 and SB3A-18, was more viscous than the less washed pair, SB3A19 and SB3A-20. The higher wt. \% total and insoluble solids content of the less washed pair were not seen as potential mitigating factors to this trend. If these properties had been closer to those of the more washed pair, then the flow curves would have been expected to have been even less viscous.

- Within the two pairs SB3A-17 to SB3A-20, the variation in the acid addition strategy had only a small impact on the SME product rheology. The direction of the variation was different in the two pairs. This could be analytical uncertainty. Another possibility is that one sample was closer to the isoelectric point $\mathrm{pH}$ (which is also the $\mathrm{pH}$ of maximum yield stress). The isoelectric point $\mathrm{pH}$ is the $\mathrm{pH}$ at which the numbers of positive and negative surface charges on a particle are equal, i.e. the particle surface has no "net" charge.

- The reduction in noble metals from SB3A-13 to the lower levels in the other five SME products had a large impact on reducing the apparent viscosity of the melter feeds. This could be related to the destruction of formate ion and formic acid driven by noble metal catalysis, which tends to reduce the soluble solids and increase the $\mathrm{pH}$ of the SME product. Formate ion was $42,300 \mathrm{mg} / \mathrm{kg}$ in the SB3A13 SME product, while it ranged from $53,450-65,900 \mathrm{mg} / \mathrm{kg}$ in SB3A-16 to 20 SME products.

- SB3A-16 was batched fairly similarly to SB3A-20. (SB3A-16 had slightly higher noble metal concentrations and slightly more acid relative to the predicted stoichiometric demand.) The two SME product rheograms were very similar, as anticipated based on the other similarities. 


\subsection{SB2/3 Melt Rate Study SME Products}

Several pairs of identically batched SRAT/SME simulations were made in the 22-L equipment. The SB2/3 blend strategy targeted the baseline SB3 scenario, Case $6 \mathrm{~b}$. The acid addition targeted $135 \%$ of stoichiometry. One pair of runs targeted a 31\% waste loading in the SME cycle, while a second pair targeted a $35 \%$ waste loading in the SME cycle. Another pair of runs made approximately $40 \%$ waste loading product. An additional pair of runs switched from the Case $6 \mathrm{~b}$ wash endpoint to the Case $7 \mathrm{~d}$ wash endpoint to help with determining the target wash point. Case $7 \mathrm{~d}$ included a wash after $\mathrm{Pu}$ addition, whereas Case $6 \mathrm{~b}$ did not include a wash after $\mathrm{Pu}$ addition. A series of runs based on the Case $6 \mathrm{~b}$ wash endpoint with different frits has been documented in WSRC-TR-2003-00466. A preliminary summary of the Case 7d melter feed was issued in SRT-GPD-2003-00129.

The SME products were ultimately fed to the SMRF. Physical property data are given in Table 2 for the SME cycle products with supporting rheological data. Case 7d is for SRAT/SME run number 1 of 2. Results for run number 2 were very similar. Data for Case $6 \mathrm{~b}$ at $40 \%$ waste loading is for a blend of the SME products from runs numbered 2 and 3.

Table 2: Physical Properties of SB2/3 SMRF Feeds

\begin{tabular}{|l|c|c|c|c|c|c|}
\hline & $\begin{array}{c}31 \%-R u n \\
1\end{array}$ & $\begin{array}{c}31 \%-\text {-Run } \\
2\end{array}$ & $\begin{array}{c}35 \%-\text { Run } \\
1\end{array}$ & $\begin{array}{c}35 \%-\text { Run } \\
2\end{array}$ & $\begin{array}{c}40 \%- \\
\text { Case 6b }\end{array}$ & $\begin{array}{c}40 \%- \\
\text { Case } 7 d\end{array}$ \\
\hline Wt. \% Total Solids & 48.80 & 49.00 & 49.55 & 48.45 & 47.7 & 49.85 \\
\hline Wt. \% Insoluble Solids & 37.10 & 37.45 & 36.95 & 35.90 & 35.0 & 38.10 \\
\hline Density (g/ml) & 1.41 & 1.41 & 1.38 & 1.44 & 1.39 & 1.31 \\
\hline pH & 7.24 & 7.41 & 8.11 & 7.43 & 6.21 & 7.57 \\
\hline Frit Type & 418 & 418 & 418 & 418 & 202 & 418 \\
\hline
\end{tabular}

Each SME product sample at $31 \%$ and $35 \%$ was analyzed twice. Reproducibility between the first and second measurement for a given sample was good. Two separate Case 7d SME products were each analyzed once. Blends of the $31 \%$ and $35 \%$ waste loading SME products from the pairs of 22-L runs were also analyzed for rheology one time each (small sample volume available). Figure 3 shows the trend that was repeated with all of the waste loading dependant data from Case $6 \mathrm{~b}(31 \%, 35 \%$, and $40 \%)$. 
Figure 3. SB2/3 Case 6b SME Product (SMRF Feed) Rheology Data

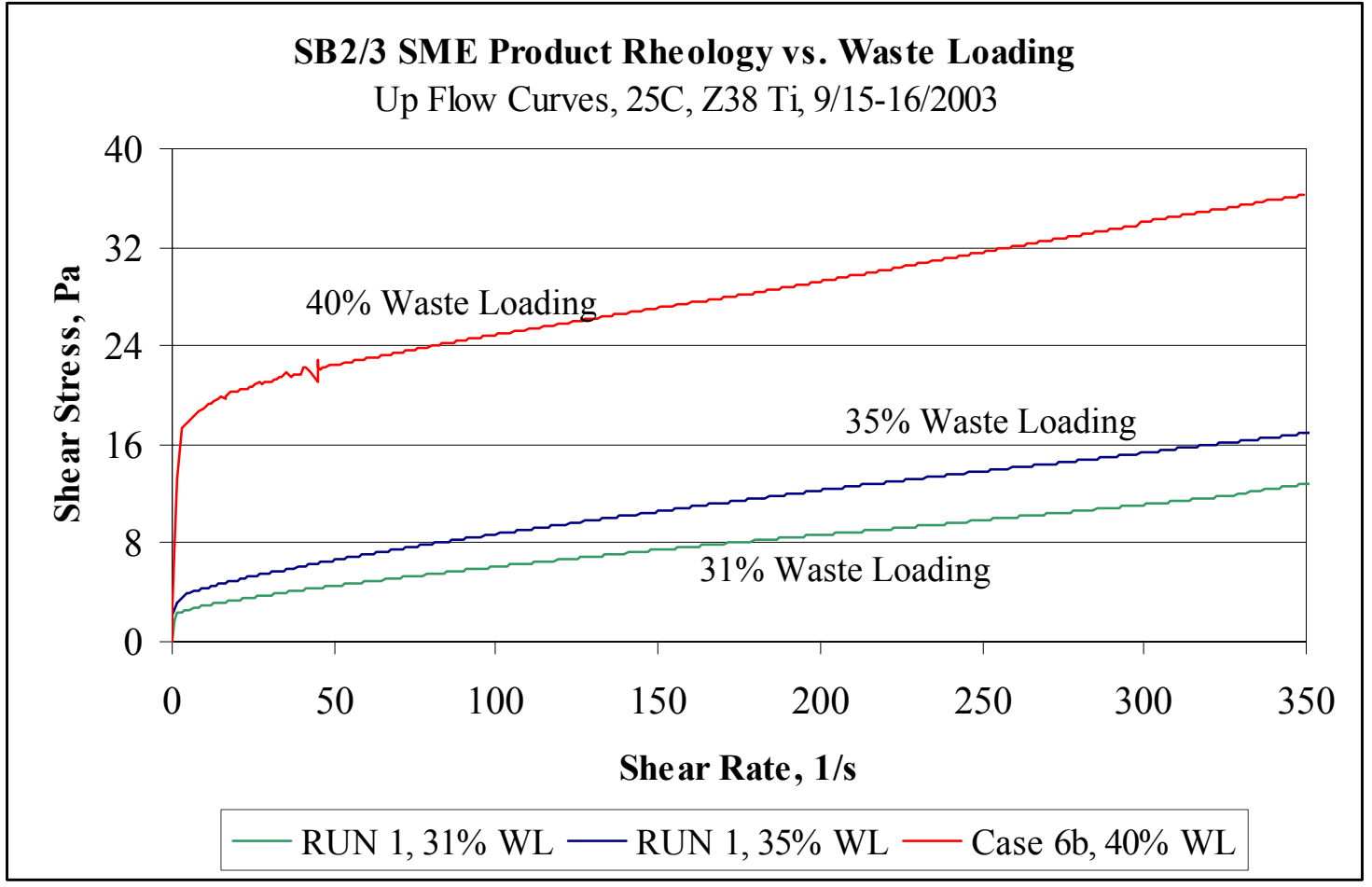

The relative rheological properties increased with increasing waste loading. This is the intuitively expected trend, since it is the colloidal sludge particles, not the coarse frit particles, which have the dominant effect on the rheology. Although there was a frit change in the $40 \%$ waste loading sample from 418 to 202, it seems unlikely that this change alone would explain the large increase in apparent viscosity that was seen.

The two 22-L 35\% SME products were combined and then sampled again. The resulting two rheograms were essentially identical to the individual SME product rheograms. The two 31\% waste loading SME products were also combined and sampled. The resulting rheograms were somewhat more viscous than either of the individual products. The blended $31 \%$ waste loading product sample may not have been representative, given the preponderance of other data.

The impact of one additional wash on the rheological properties of SB2/3 simulant SME product at $\sim 40 \%$ waste loading is shown in Figure 4. 
Figure 4. SB2/3 SME Product (SMRF Feed) Rheology Data vs. Wash Endpoint

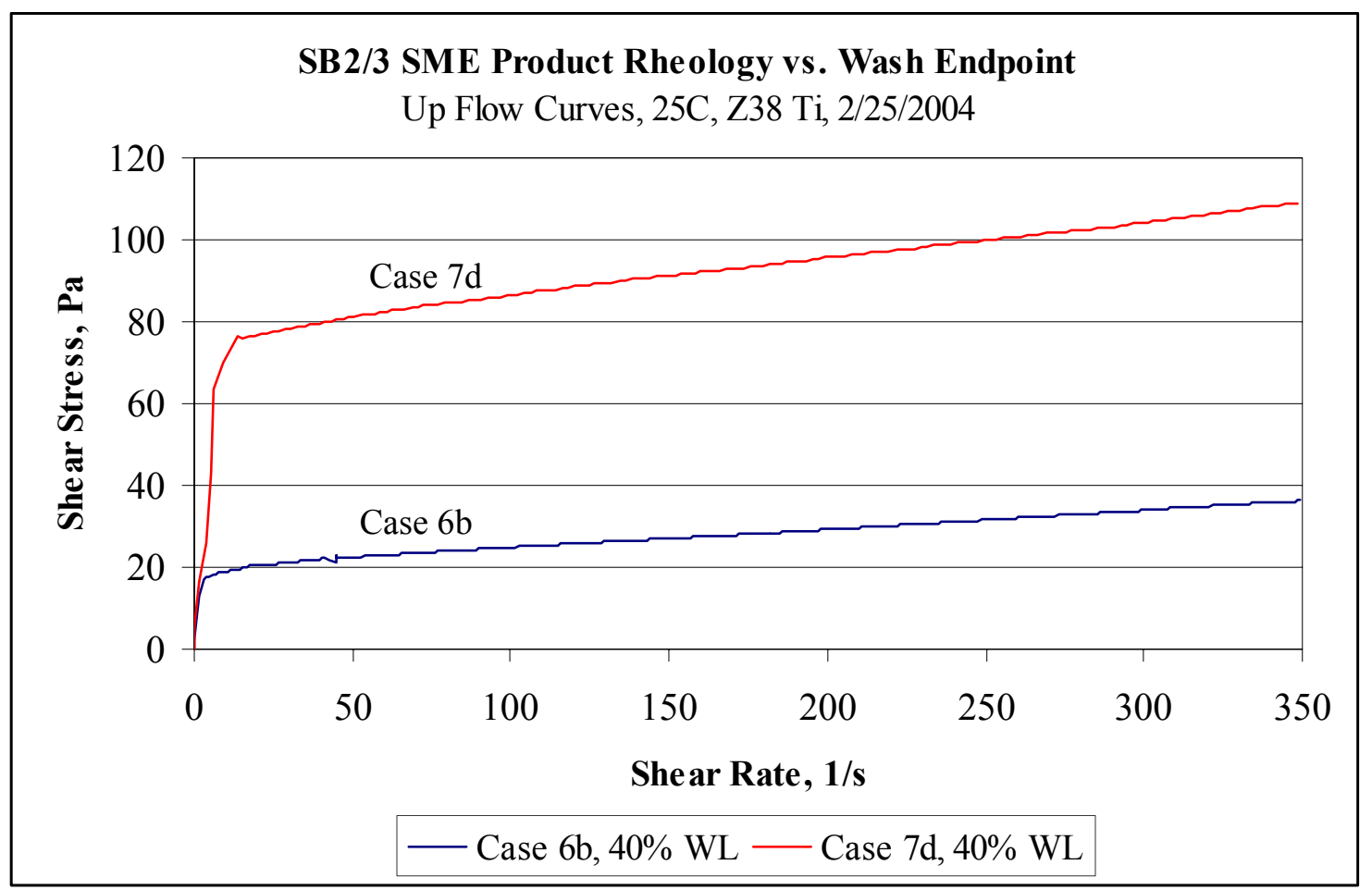

The more-washed SME product, Case $7 \mathrm{~d}$, was extremely thick (not truly pourable). The Case $7 \mathrm{~d}$ curve shown was the less viscous of two measurements (one measurement was made on each of the two SME products produced in the two 22-L SRAT/SME simulations.) While both cases fall outside the DWPF design basis (yield stress of $15 \mathrm{~Pa}$ ), the less-washed Case 6b SME product could be processed in the lab and readily fed to the SMRF. It could be poured from a bottle after it was shaken. The Case 7d SME product needed assistance to get out of the sample bottle. Simulants, however, are not perfect matches to real waste slurries, so the rheological data are more relevant as indicators of tendencies. Data on SB3 SME products at two different starting nitrite ion concentrations also suggested that less washing was helping to keep the SME product less viscous (see Figure 2). These data were at higher nitrite ion concentrations than the $\mathrm{SB} 2 / 3$ blend, but tend to support the conclusion that more washing was leading to more viscous SME products.

\subsection{SB2/3 Flow Sheet Study SME Products}

Four SRAT/SME simulations were performed with SB2/3 simulant in the 4-L equipment at ACTL. The sludge targeted a Case 6b (no washing) supernate composition for SB3. This was blended with SB2 assuming a February 2004 date for the combination. Additional details can be found in WSRC-TR-200400042. The starting sludge was very similar to that used in the preparation of the SMRF feeds described in the previous section. The primary difference was an increase in wt. $\%$ total solids during the SRAT cycle. This had implications for the acid requirement to destroy nitrite to less than $1000 \mathrm{mg} / \mathrm{kg}$ during the SRAT cycle.

Two complete sets of rheological measurements were made on the four SME products. The first set was made using the Z38 bob. The second set was made using the Z31 bob (results reported in WSRC-TR2004-00042). Taylor vortices probably formed late in the up ramp portion of the measurement in both sets of measurements. Radial circulation patterns can potentially segregate solids in the annular gap of 
the rheometer. Therefore, the down flow portions of the data, which were obtained after Taylor vortices had formed, were not considered further in evaluating the data.

Table 3 gives physical property data for the four SME products produced in the SB2/3 flow sheet study on the impact of acid addition. Frit 432, a derivative of frit 418 , was used in all four tests.

Table 3: SB2/3 SME Product Properties

\begin{tabular}{|l|c|c|c|c|c|}
\hline Acid Stoichiometry: & $135 \%^{1}$ & $140 \%$ & $155 \%$ & $170 \%$ & $185 \%$ \\
\hline Wt. \% Total Solids & 49.00 & 50.35 & 50.55 & 49.90 & 49.80 \\
\hline Wt. \% Insoluble Solids & 36.43 & 40.25 & 39.65 & 38.85 & 38.40 \\
\hline Density $(\mathrm{g} / \mathrm{ml})$ & 1.41 & 1.51 & 1.43 & 1.46 & 1.35 \\
\hline $\mathrm{pH}$ & 7.77 & 7.64 & 7.09 & 5.79 & 4.76 \\
\hline
\end{tabular}

1. Not part of the 4-L study, but included here for comparison purposes (average of two results).

Figure 5 gives the well-behaved portions of the up ramp flow curves. This plot excludes the high shear rate region where Taylor vortices were observed. The 35\% waste loading SMRF feed at $135 \%$ acid has been included on this plot as additional data related to the impact of acid addition on SME rheology. It had compositional properties that were very similar to the four melter feeds prepared during the SB2/3 flow sheet study, but used a different frit.

Figure 5. Z38 SB2/3 SME Product Rheology as a Function of Acid Stoichiometry

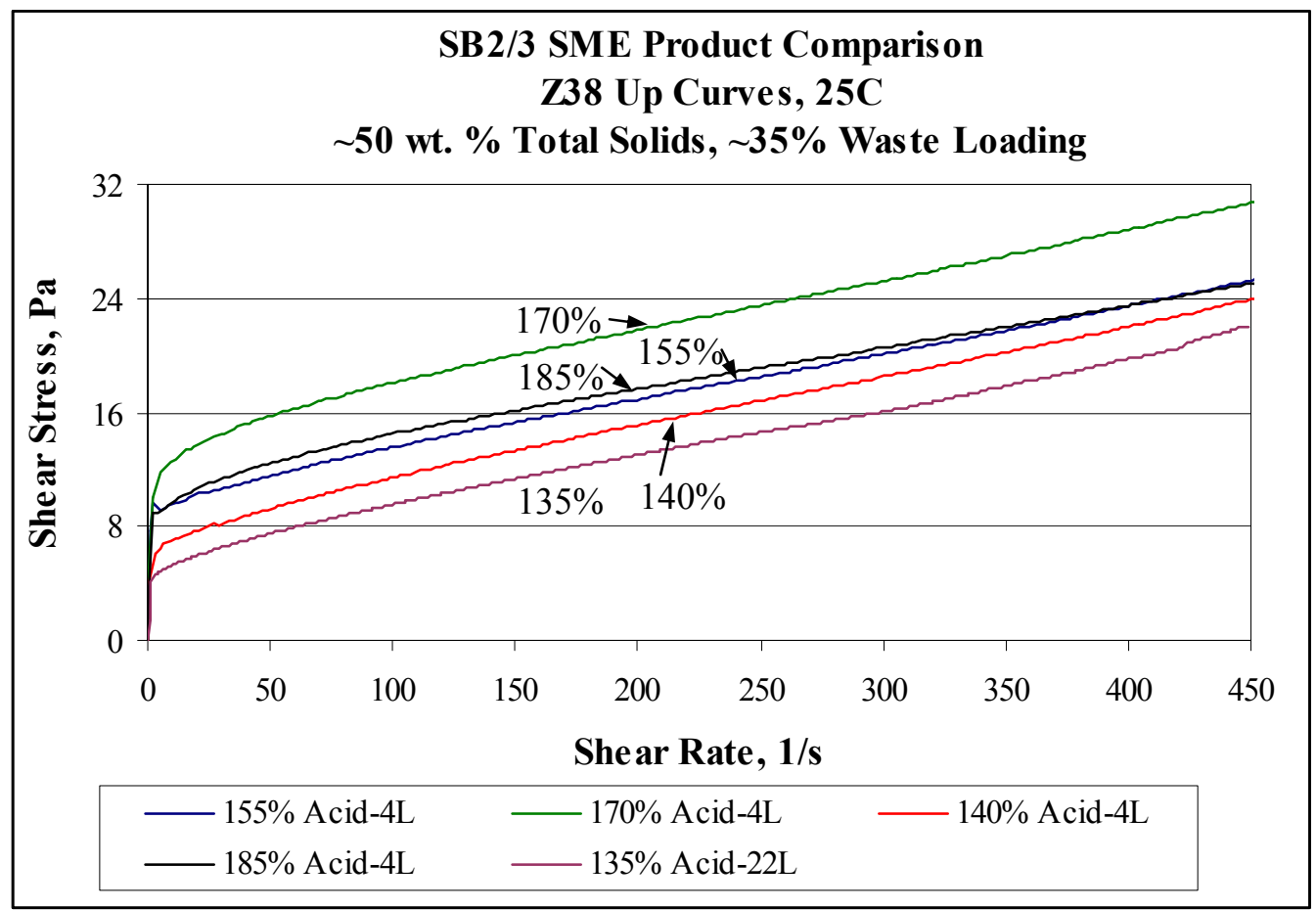

The SME products become more viscous as the SRAT acid stoichiometry increased from $135 \%$ to $140 \%$ to $155 \%$ to $170 \%$. The $185 \%$ acid stoichiometry SME product reversed the trend by becoming less viscous than the $170 \%$ SME product. 
Figure 6 gives data similar to Figure 5, except that it was taken using the smaller diameter Z31 bob instead of the Z38 bob. There are no comparable data for the SMRF feed with the Z31 bob, so only the four SME products from the flow sheet acid addition study are shown.

Figure 6. Z31 SB2/3 SME Product Rheology as a Function of Acid Stoichiometry

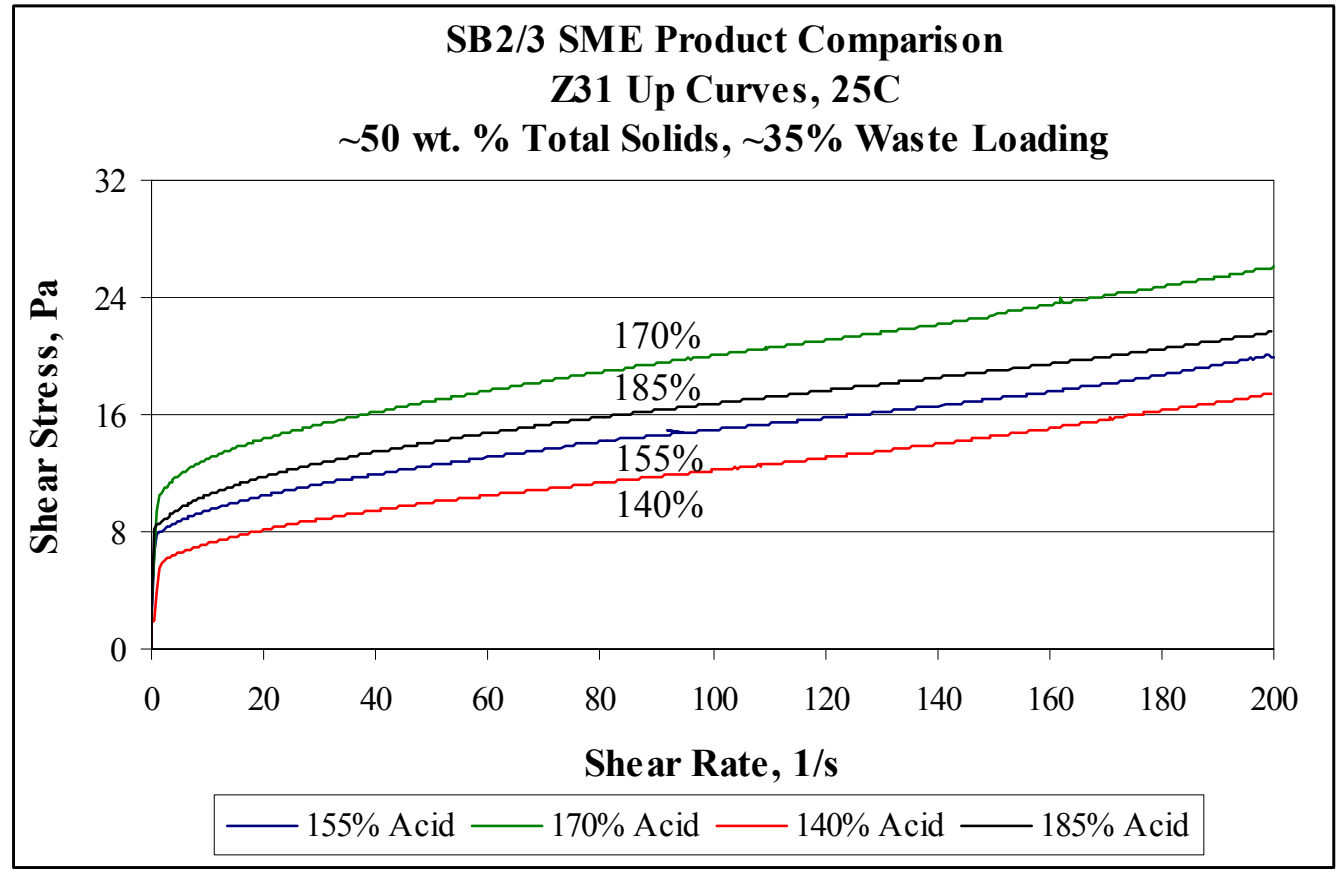

The same trend with acid stoichiometry was observed in this measurement set. The SME products became more viscous as the acid addition was increased from $140 \%$ to $170 \%$ of stoichiometry. The trend reversed when the acid addition was increased further to $185 \%$ of stoichiometry. The yield stress, as set by the interception of the linear portion of the up curve with the shear stress axis, seemed to remain approximately constant between the Z31 and Z38 data sets, but consistencies (slopes) were lower in the Z38 data. Taylor vortices are evident in the later parts of the flow curves for the 140 and 155\% SME products (the flow curves bend up somewhat).

The production of hydrogen increased sharply between the simulation at $170 \%$ and the one at $185 \%$ (see WSRC-TR-2004-00042). This was accompanied by some changes in how the supernate chemistry of the SME products correlated with the amount of total acid added. For example, formate ion concentration increased successively from $140 \%$ to $155 \%$ to $170 \%$, but then decreased in the $185 \%$ SME product relative to the $170 \%$ SME product. This trend tracked the rheological data. Nitrate increased successively from $140 \%$ to $155 \%$ to $170 \%$, then held steady between $170 \%$ and $185 \%$.

Available literature on colloidal slurry rheology indicates that the yield stress of a system goes through a maximum at the $\mathrm{pH}$ corresponding to the isoelectric point of the solids. This $\mathrm{pH}$ is often in the mid-pH's ( $\mathrm{pH}$ from 5-9) for complex colloidal solids (solids containing many elements). This is one possible explanation for the maximum in apparent viscosity associated with the $170 \%$ acid stoichiometry SME product. It may have been the one sample in the set that was closest in $\mathrm{pH}$ to the isoelectric point for $\mathrm{SB} 2 / 3 \mathrm{SME}$ products. This may be a different isoelectric point $\mathrm{pH}$ than is found for SRAT products due to the addition of the frit to the slurry. Visual observation of these samples also showed that the SME product became lighter in color (from dark to medium brown) as more acid was added. 


\subsection{SB2/3 Flow Sheet Study SRAT Products}

Four SRAT/SME simulations were performed in the 4-L equipment at ACTL using SB2/3 starting sludge as described in Section 3.3. The starting sludge was 23.9 wt. \% total solids. The runs targeted $140 \%$, $155 \%, 170 \%$ and $185 \%$ of the stoichiometric acid demand. SRAT product samples for rheology were pulled prior to starting the SME cycle. Properties of the four SRAT products are given in Table 4.

Table 4: SB2/3 SRAT Product Properties

\begin{tabular}{|l|c|c|c|c|}
\hline Acid Stoichiometry: & $140 \%$ & $155 \%$ & $170 \%$ & $185 \%$ \\
\hline Wt. \% Total Solids & 27.25 & 28.20 & 28.90 & 29.10 \\
\hline Wt. \% Insoluble Solids & 14.85 & 14.30 & 14.15 & 13.25 \\
\hline Density (g/ml) & 1.12 & 1.23 & 1.25 & 1.21 \\
\hline pH & 7.6 & 7.19 & 5.02 & 4.53 \\
\hline
\end{tabular}

Two rheological measurements were made on each SRAT product. The first measurements are given in Figure 7. The second measurements are given in Figure 8.

Figure 7. First Rheograms of SB2/3 SRAT Products

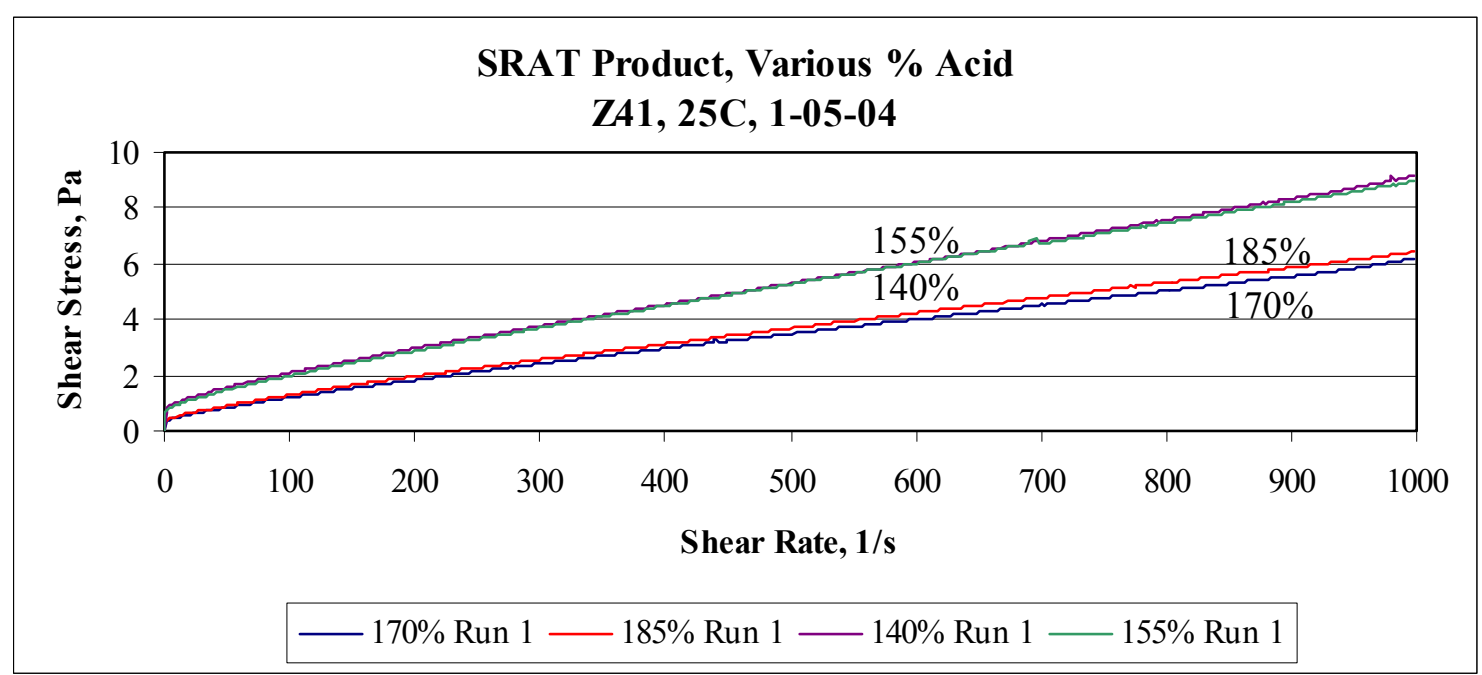


Figure 8. Second Rheograms of SB2/3 SRAT Products

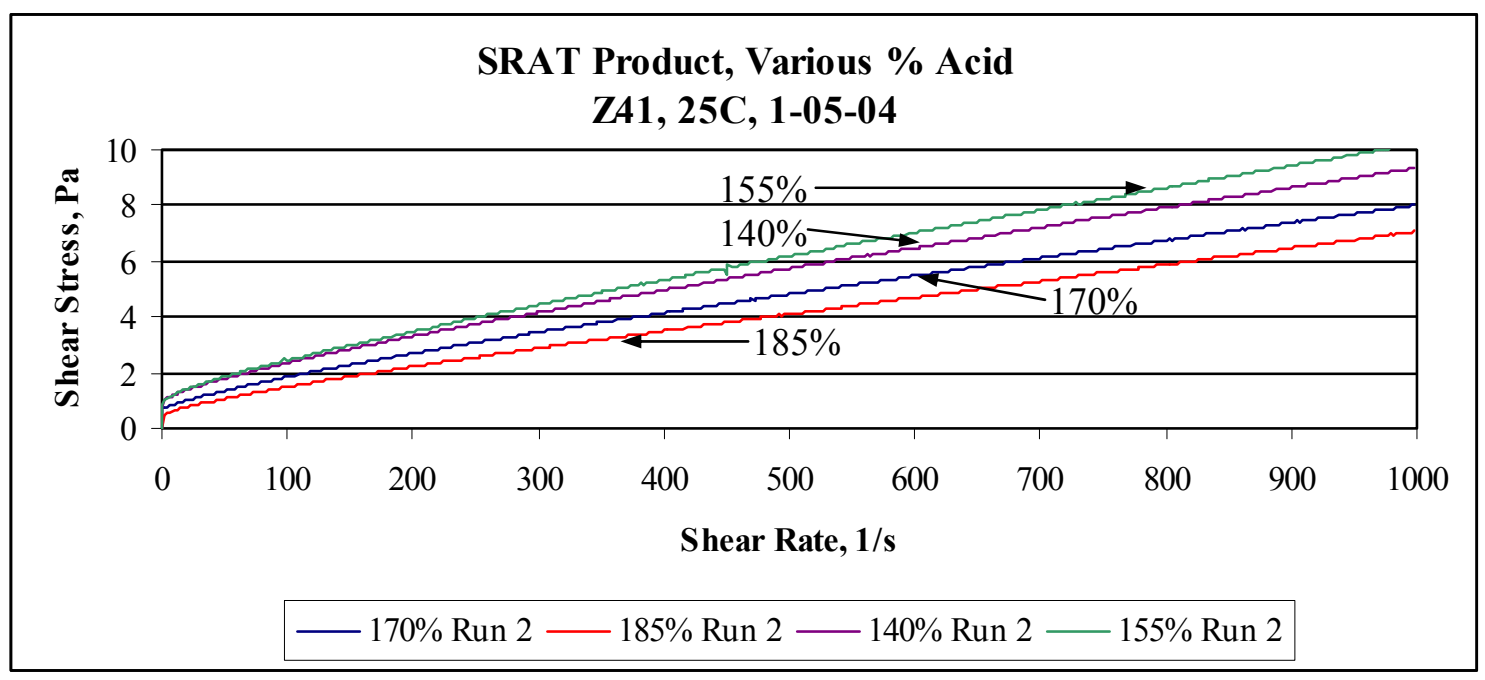

The samples were not very viscous. Yield stresses appeared to be less than $20 \mathrm{dynes} / \mathrm{cm}^{2}$, even though the solids contents were fairly high. There was a general trend indicating that the SRAT products became less viscous as the acid stoichiometry was increased. The effect was not very big, and it was partially obscured by issues of reproducibility in the measurements. The $140 \%$ and $155 \%$ product rheological results were almost identical in the first run, and the $155 \%$ was measured as slightly thicker in the second run. The $170 \%$ and $185 \%$ results were almost identical in the first run, and the $185 \%$ was clearly thinner than the $170 \%$ product in the second run. The $140 \%$ and $155 \%$ pair was clearly more viscous than the $170 \%$ and $185 \%$ pair in both measurements.

It could be argued that the $155 \%$ acid SRAT product was the most viscous on average, instead of the $140 \%$ acid. If so, this could be another case of the sample nearest the isoelectric point of the system having the highest yield stress. If so, it could indicate that the isoelectric point $\mathrm{pH}$ of the SRAT product is higher than that of the SME product. It is worth noting that the SME cycle seemed to significantly alter the rheological trends with respect to acid addition relative to those of the SRAT products (see discussion in section 3.3).

\subsection{SB2/3 Flow Sheet Study SME Product Supernates}

Two supernate phase samples were separated from two of the SB2/3 SME products discussed in section 3.3. These were free of insoluble solids and very fluid. They were taken from the $140 \%$ and $185 \%$ stoichiometry SME products. The viscosity of these two supernates was measured using the rheometers at ACTL. The two supernates behaved like Newtonian fluids, and the data was fit accordingly. Both viscosities were small. Therefore the measurements were made using the cone-and-plate geometry $\left(0.5^{\circ}\right.$ angle cone on a $60-\mathrm{mm}$ diameter plate). The viscosity of the $140 \%$ supernate was $1.47 \mathrm{cP}$. The viscosity of the $185 \%$ supernate was $1.44 \mathrm{cP}$. These results do little to explain the differences in apparent viscosity of the associated SME product slurries. The raw rheological data are given in Appendix B.

\subsection{Impact of Formic Acid Dump on SB2/3 Flow Sheet Study SME Products}

The four SME products from the acid addition impact on flow sheet study described in section 3.3 were subjected to an additional formic acid addition. The targets and results of the initial rheological measurements are summarized in WSRC-TR-2004-00042 (results are reproduced in Appendix B as well). 
The second set of rheological measurements was essentially identical to the first. These flow curve results are given in Figure 9.

Figure 9. Impact of Formic Acid Dump on SB2/3 SME Product Rheology

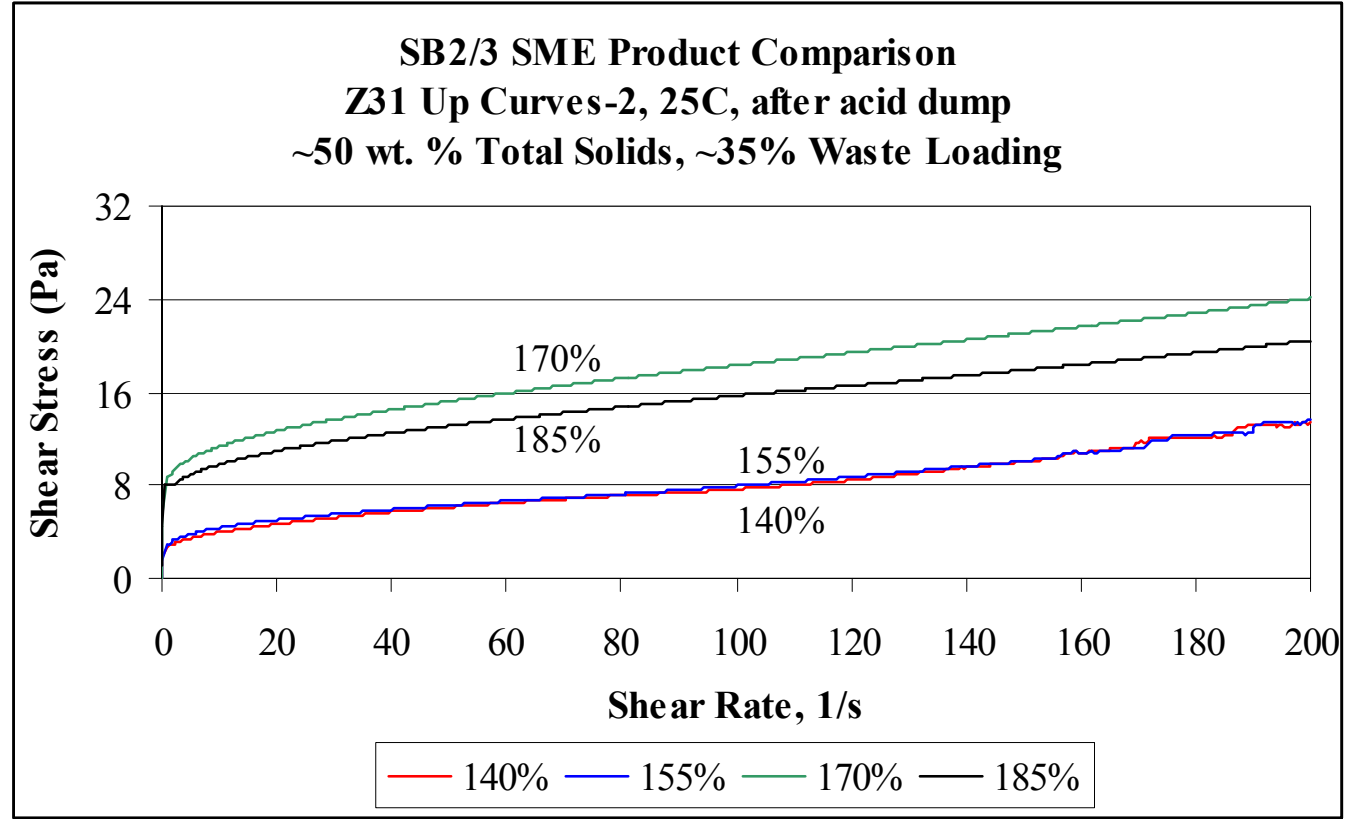

Three of the SME products were noticeably thinned by the addition of formic acid following SME cycle processing. The impact of the formic acid dump on the rheological behavior of the $155 \%$ acid SME product is shown in Figure 10. 
WSRC-TR-2004-00116

Revision 0

Figure 10. Impact of Formic Acid Dump on 155\% Acid SME Product

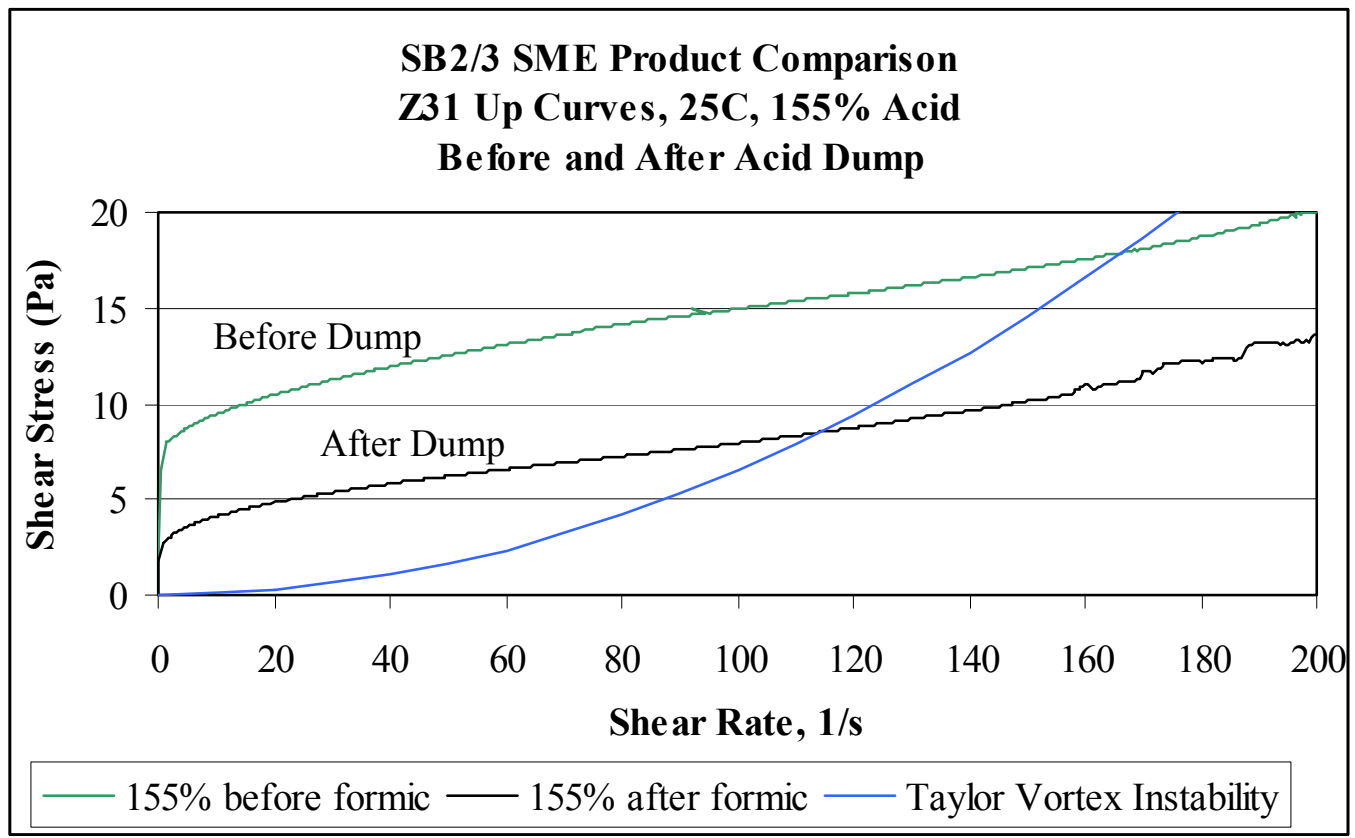

The shear stress required to move the sample was only about half as large after the formic acid dump as it was before the dump. The blue curve shows the predicted location for the onset of Taylor vortices with the Z31 bob annular gap. Rheological data below the curve cannot be used. Plots for the 140\% comparison and the 170\% comparison are given in Appendix B. The impact of the formic acid dump on the $185 \%$ acid SME product, however, was minimal by comparison. This is shown graphically in Figure 11. 
WSRC-TR-2004-00116

Revision 0

Figure 11. Impact of Formic Acid Dump on 185\% Acid SME Product

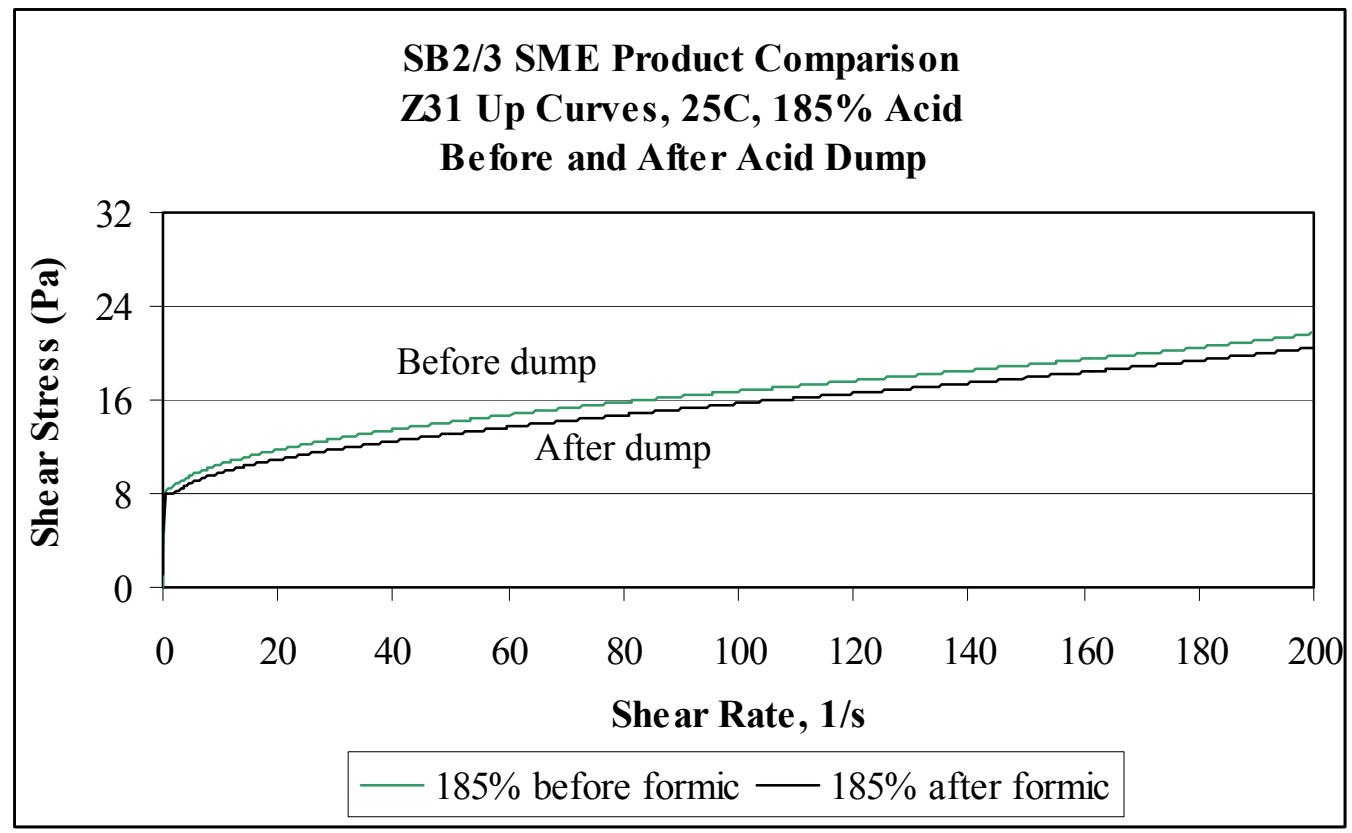

These curves are within the typical range of measurement reproducibility that is seen on the Haake rheometers at ACTL. The low $\mathrm{pH}$ of the $185 \%$ SME product $(\mathrm{pH}=4.76)$ before the formic acid dump may explain the lack of a rheological impact. The formic acid dump was probably ineffective at producing much of a $\mathrm{pH}$ change in the $185 \%$ system relative to the other three SME products that were initially at higher $\mathrm{pH}$ 's. There is a small dilution of the insoluble solids that occurs when making the formic acid dump that should lead to a slightly less viscous product even if there is no $\mathrm{pH}$ change. That may have been seen in the data for the $185 \%$ SME products before and after the dump, but the data are not conclusive since they lie within the range of experimental uncertainty. This entire set of data could be taken as further confirmation of the significant role of $\mathrm{pH}$ in controlling SME product rheology.

\subsection{Shielded Cells Data}

The Shielded Cells received a sample of Tank 51 waste prior to the addition of $\mathrm{Pu}$ and Np streams. These two trim streams were prepared from samples available in SRTC and added to the Tank 51 sample in a simulation of the proposed decanting and addition steps in the Tank Farm. Details can be found in WSRC-TR-2004-00050. This sludge was considered bounding for SB3 processing and underwent the SRTC qualification process. A sample of the trimmed sludge used in the SRAT simulation was analyzed using the RV30 rheometer in the Shielded Cells. This data is shown in Figure 12. 
WSRC-TR-2004-00116

Revision 0

Figure 12. Rheological Data for SB3 Sludge Used in Qualification Work

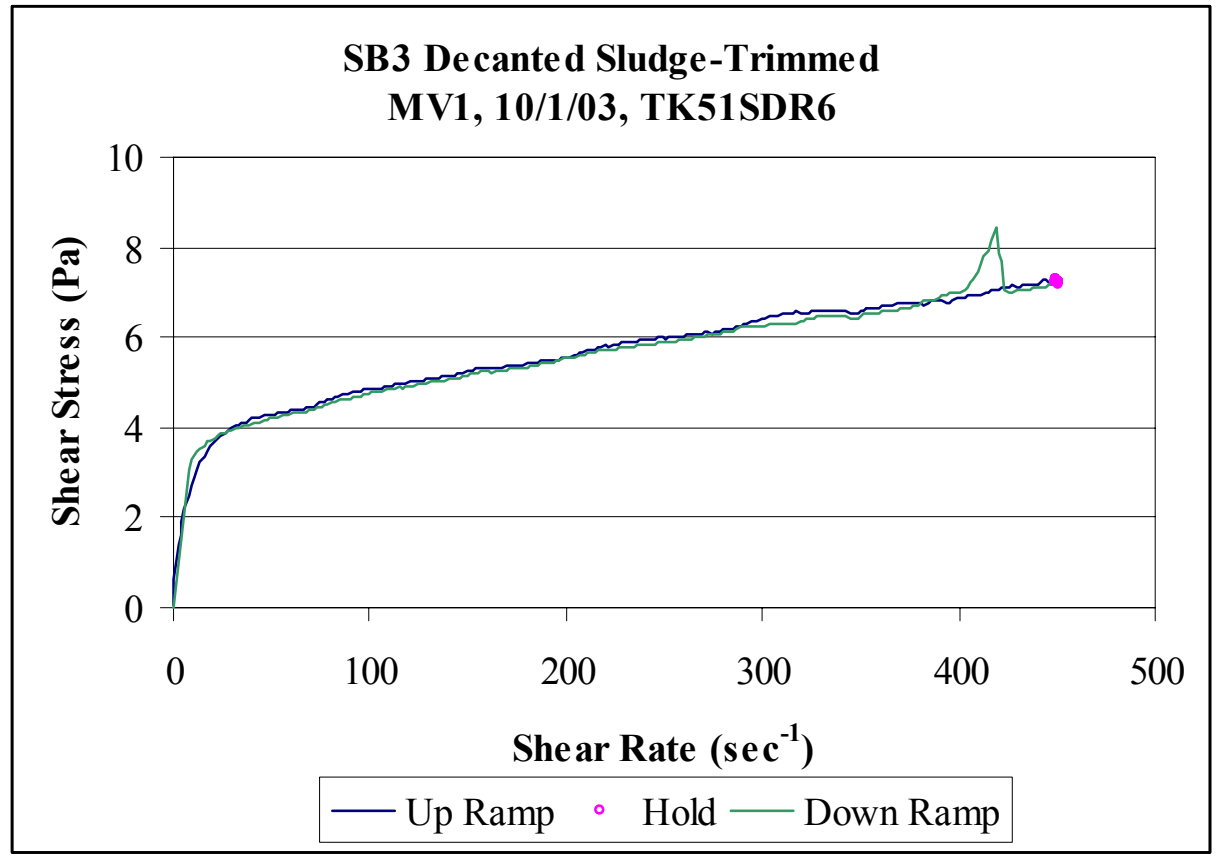

The sample was less viscous than the SB2 qualification sample. Data are for $25^{\circ} \mathrm{C}$.

Some of the SB3 decanted sludge was mixed with some of the 2003 SB2 sludge sample in proportions anticipated to approximate the blending ratio of SB2 with SB3 in the Tank Farm. Details can be found in WSRC-TR-2004-00097. This sample was also analyzed using the RV30 rheometer in the Shielded Cells. One purpose was to attempt to spot any processing issues that might arise from blending the two sludge batches together. This data is shown in Figure 13. 
Figure 13. Preliminary Rheological Data for SB2/3 Blended Sludge

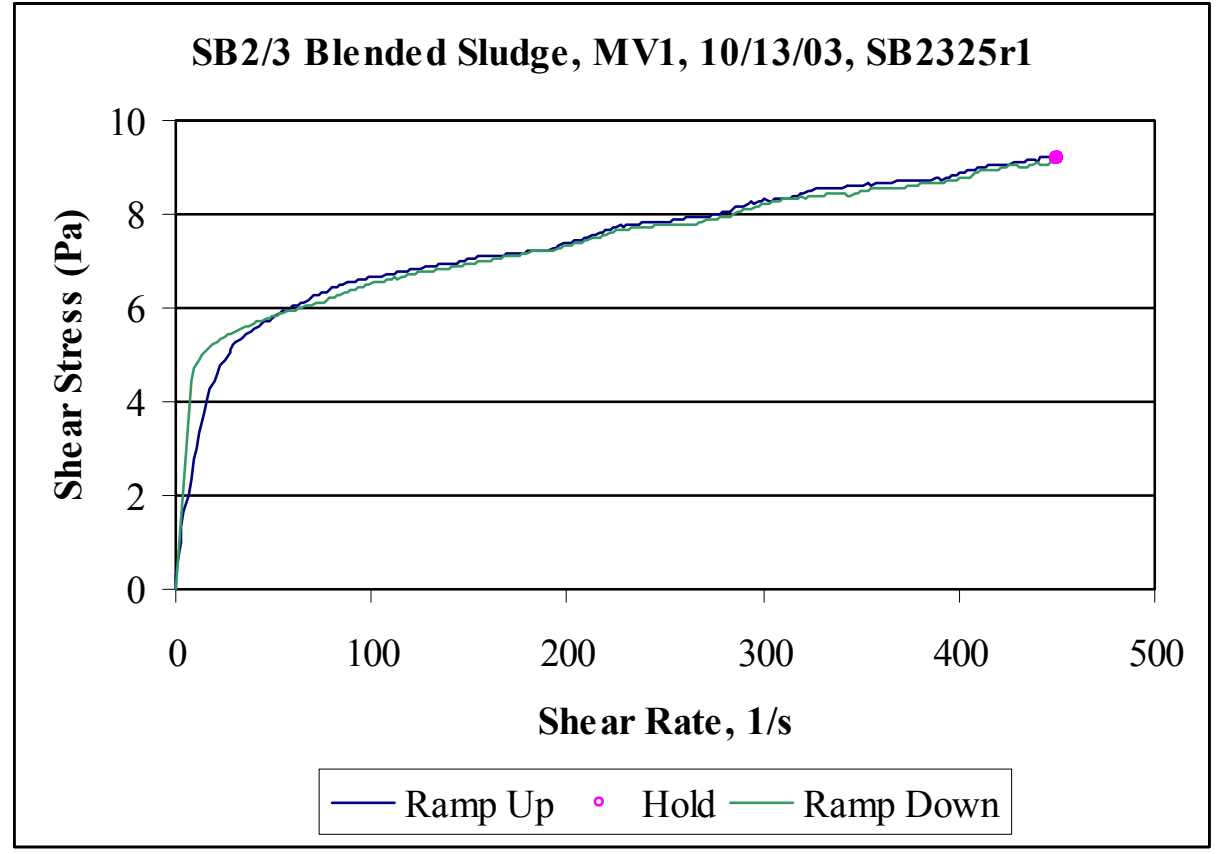

The blended SB2 and SB3 sludge slurry was more viscous than the SB3 slurry, but less viscous than the SB2 slurry. The SB2/3 data are preliminary in the sense that the sample was synthesized in SRTC, rather than coming directly from Tank 40 after all additions had been made. Data are at $25^{\circ} \mathrm{C}$.

Up and down flow curves are given in Figure 14 for the three radioactive sludges.

Figure 14. Comparison of the Three Radioactive Sludge Rheograms.

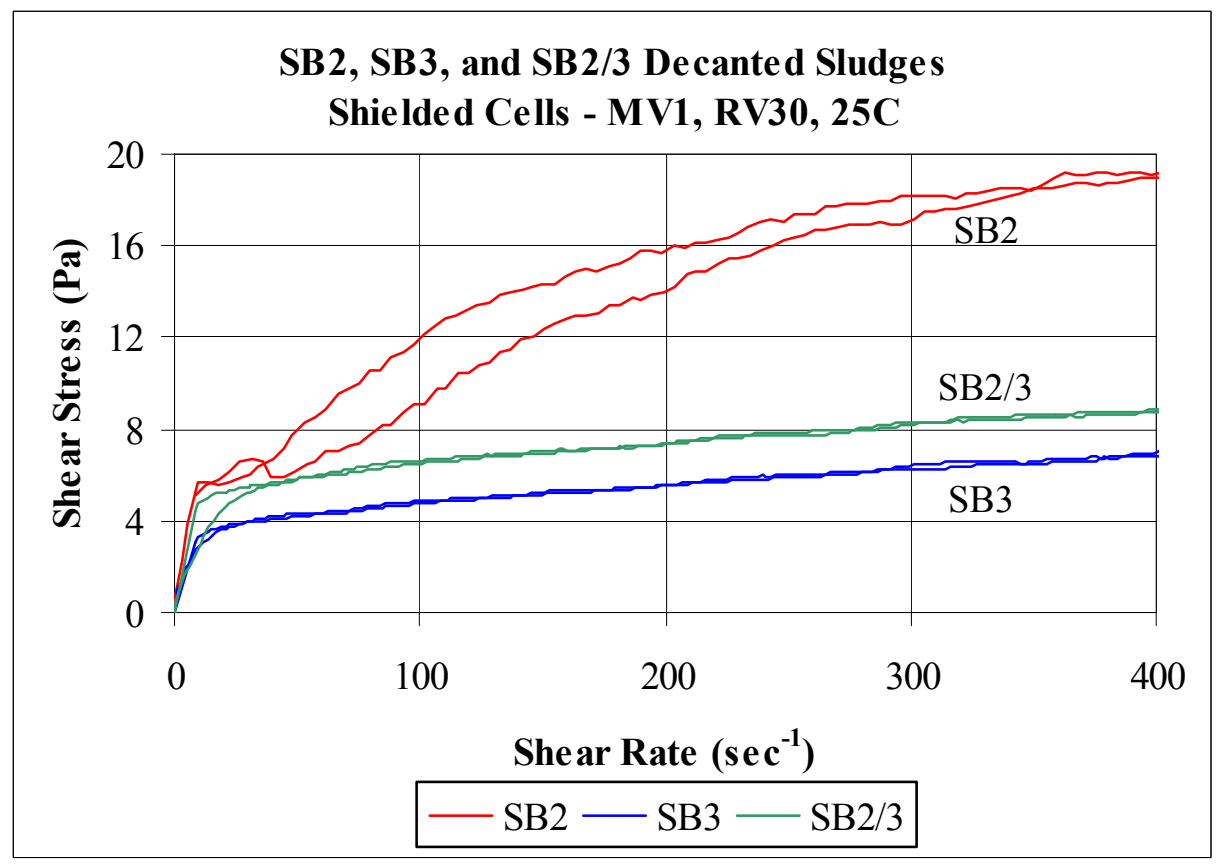




\subsection{CONCLUSIONS}

Listed below are the major conclusions and observations that came from the rheological data for SB3 and SB2/3 simulant samples.

1. Higher waste loading tended to increase the apparent viscosity at constant wt. $\%$ total solids for SB2/3 SME products at $31 \%, 35 \%$, and $40 \%$ waste loading.

2. Higher acid additions tended to reduce the apparent viscosity of SB2/3 SRAT products when the $\mathrm{pH}$ was away from 7. As SRAT products neared $\mathrm{pH} 7$, they tended to be more viscous.

3. Higher SRAT acid addition had a reverse effect on the SB2/3 SME products. Higher acid additions tended to increase the apparent viscosity of corresponding SME products until the $\mathrm{pH}$ dropped below about 6 . The SME product at $140 \%$ stoichiometry was the least viscous of the four products in the acid addition impact study, while the SME product at $170 \%$ was the most viscous. SME products at $155 \%$ and $185 \%$ fell in between.

4. The SB2/3 35\% waste loading SME product made for SMRF testing fit well with the SB2/3 acid addition study runs. This run was at $135 \%$ acid. Its SME product was less viscous than the $140 \%$ acid run SME product.

5. The more washed SB2/3 Case $7 \mathrm{~d}$ SME product was extremely thick compared to the comparable SB2/3 Case $6 \mathrm{~b}$ SME product. The exact cause of this has not yet been identified. This was consistent with the trend seen for the different nitrite endpoint target SB3 sludges.

6. For the SME product supernates that were measured, viscosity was only slightly higher than that of water. The viscosity barely changed between the $140 \%$ acid case and the $185 \%$ acid case. This data did not provide any insight as to why the $140 \%$ acid case SME product slurry was less viscous than the $185 \%$ acid case SME product slurry.

7. The formic acid dump produced a lower viscosity SME product. The effect that was achieved seemed dependent on the $\mathrm{pH}$ of the SME product prior to the dump. Low $\mathrm{pH}$ SME products $(\mathrm{pH}<5)$ were less affected than high $\mathrm{pH}$ SME products $(\mathrm{pH}>7)$.

The major conclusion drawn from the new rheological data for SB3 and SB2/3 radioactive sludge samples was that SB3 sludge was less viscous than SB2 sludge, while the blend of the two sludges had intermediate properties. 


\subsection{RECOMMENDATIONS/PATH FORWARD}

The data obtained on SME and SRAT products suggests a significant role for $\mathrm{pH}$ in rheology. No data like these have been found in the previous measurement sets for prior sludge batches (SB2 testing, WSRC-TR-2001-00051, at three acid levels did not produce much of a $\mathrm{pH}$ range in the SRAT products due to the effect of the noble metals). Small $\mathrm{pH}$ adjustments to SB2/3 SME products could be made using concentrated caustic or nitric acid. This would create a series of SME products with different pH's. These could be characterized to better define the $\mathrm{pH}$ region associated with the maximum yield stress.

The impact of wash endpoint on the SB2/3 SME product rheology was large in the washing range that was studied. An effect was also seen in the SB3 SME product rheology data. The factors that contribute to this probably come from the list of $\mathrm{pH}$, soluble and insoluble solids concentrations, and frit type, since identical sludge simulants were used as the basis to prepare the various wash end points that were used in the tests. Further studies focused on these factors could be made in smaller scale equipment to better understand the impact of washing and processing on SME product rheology.

Additional SB2/3 studies will be performed in March-April 2004 to look at effects of redox, waste loading, and the acid dump. 


\subsection{REFERENCES}

Baich, M.A., D.R. Best, T.K. Snyder, and M.F. Williams, Sludge Batch 2-3 Blend Flowsheet Simulations: Determination of Acid Addition Window (U). WSRC-TR-2004-00042, Savannah River Site, Aiken, SC 29808 (February 10, 2004).

Bannochie, C.J., J.M. Pareizs, and D.C. Koopman, Sludge Batch 2/3 Blend SRAT Cycle in the SRTC Shielded Cells (U). WSRC-TR-2004-00097, Savannah River Site, Aiken, SC 29808 (March 2004).

Herman, C.C., D.C. Koopman, D.R. Best, T.K. Snyder, and M.F. Williams, Sludge Batch 3 Simulant Flowsheet Studies: Final Phase SRAT/SME Results (U). WSRC-TR-2003-00422, Savannah River Site, Aiken, SC 29808 (September 30, 2003).

Koopman, D.C., C.C. Herman, D.R. Best, and M.F. Williams, Sludge Batch 3 Simulant Flowsheet Studies: Preliminary Phase III SRAT/SME Results (U). WSRC-TR-2003-00283, Savannah River Site, Aiken, SC 29808 (September 9, 2003).

Koopman, D.C., Sludge Batch 2 (Macrobatch 3) Rheology Studies with Simulants (U). WSRC-TR-200100051, Savannah River Site, Aiken, SC 29808 (February 23, 2001).

Pareizs, J. M., D.C. Koopman, D.R. Click, A.D. Cozzi, and N.E. Bibler, Sludge Batch 3 Qualification in the SRTC Shielded Cells(U). WSRC-TR-2004-00050, Savannah River Site, Aiken, SC 29808 (March 2004).

Smith, M.E., Preliminary Summary of SMRF SB2/SB3 (Case 7d - 250 Canisters) Frit 418 Test (U). SRT-GPD-2003-00129, Savannah River Site, Aiken, SC 29808 (October 9, 2003).

Smith, M.E., T.H. Lorier, and T.M. Jones, SMRF and MRF DWPF Melt Rate Testing for SB2/SB3 (Case $6 b-250$ Canisters) (U). WSRC-TR-2003-00466, Savannah River Site, Aiken, SC 29808 (October 30, 2003). 
WSRC-TR-2004-00116

Revision 0

This page intentionally left blank. 
WSRC-TR-2004-00116

Revision 0

APPENDIX A. SB3 Flow Sheet Study Rheology Data 
This is the raw flow curve data for SB3A-13.

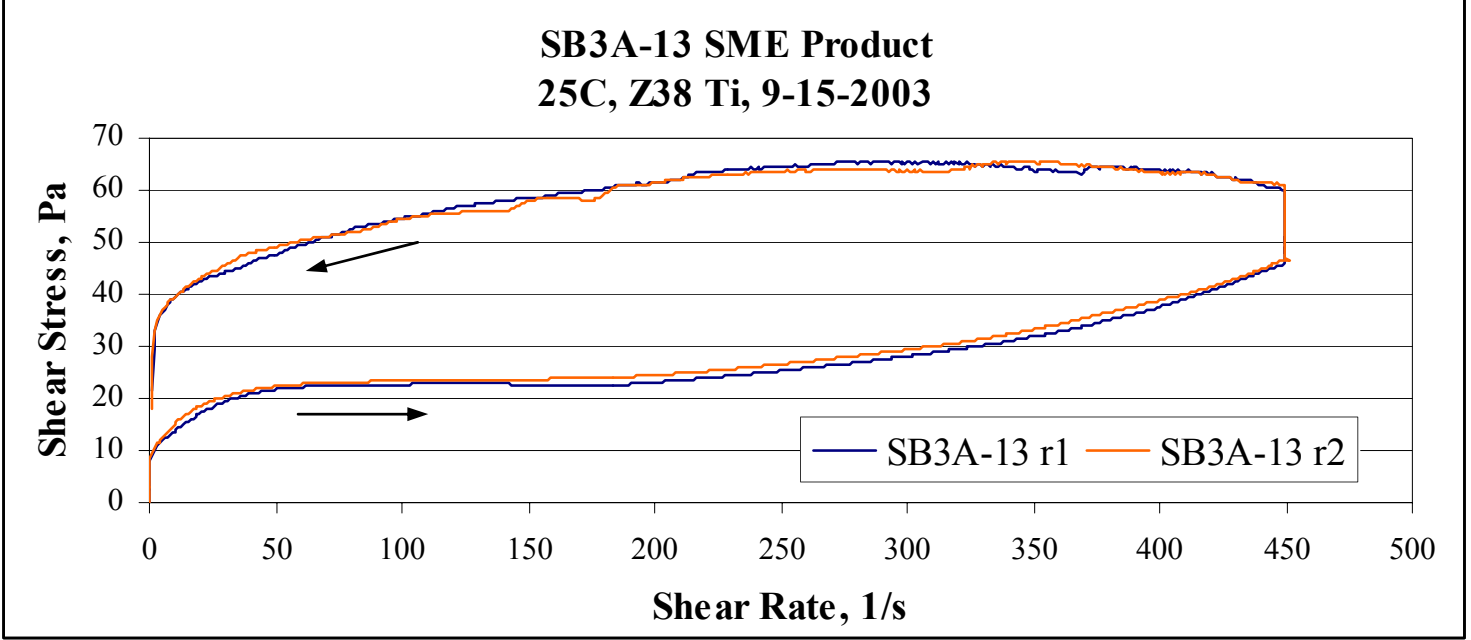

This is the raw flow curve data for SB3A-16 (best three of five measurements).

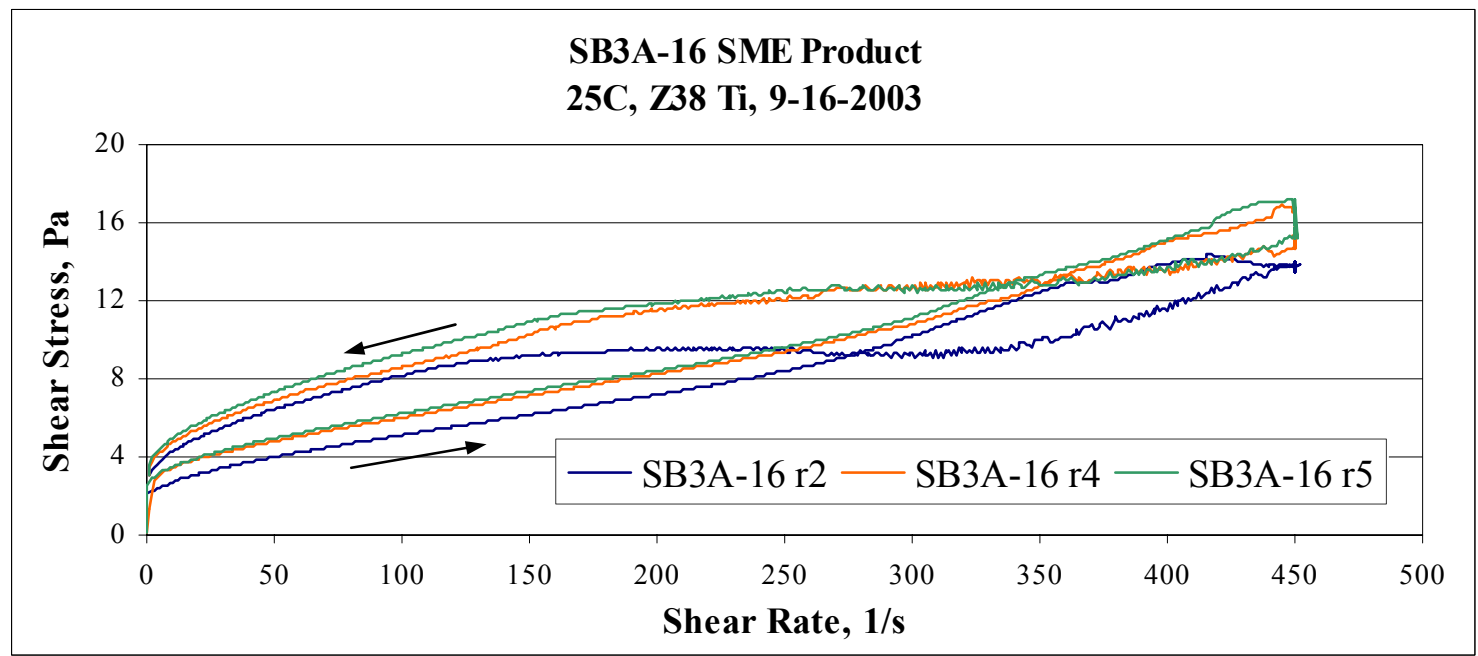

This is the raw flow curve data for SB3A-17.

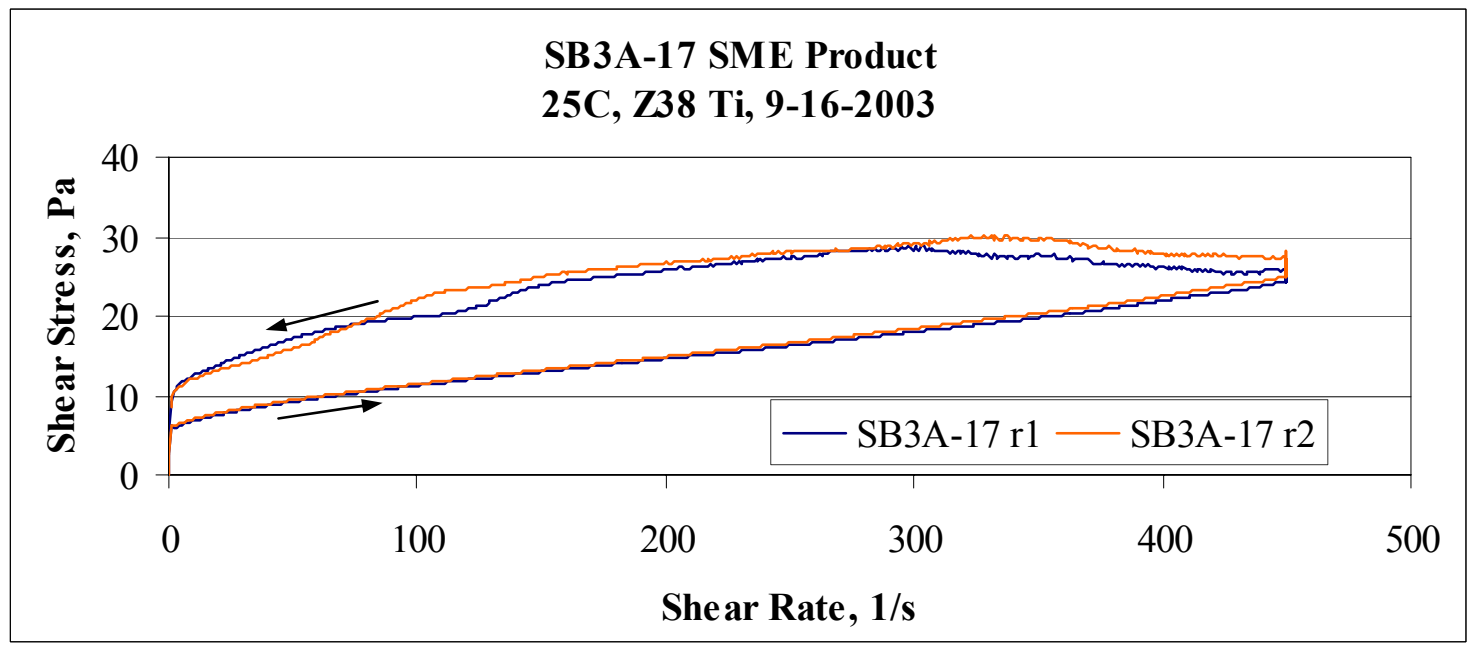


This is the raw flow curve data for SB3A-18.

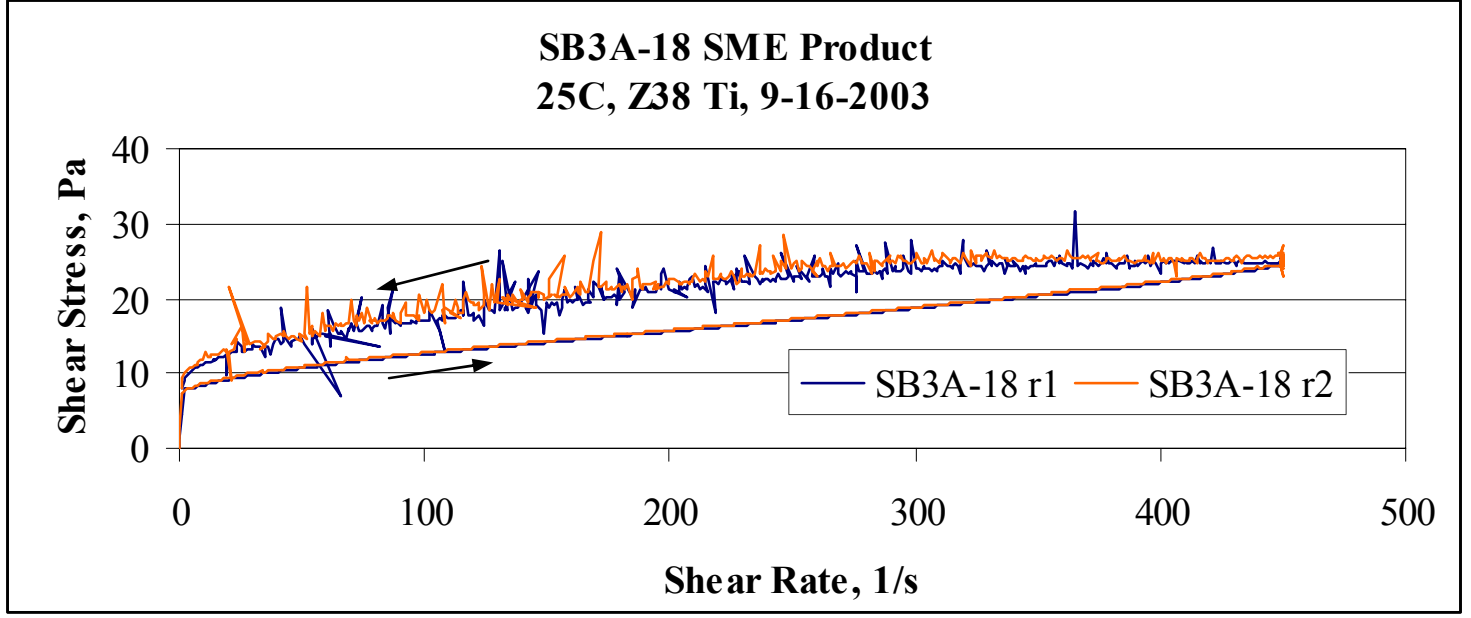

This is the raw flow curve data for SB3A-19.

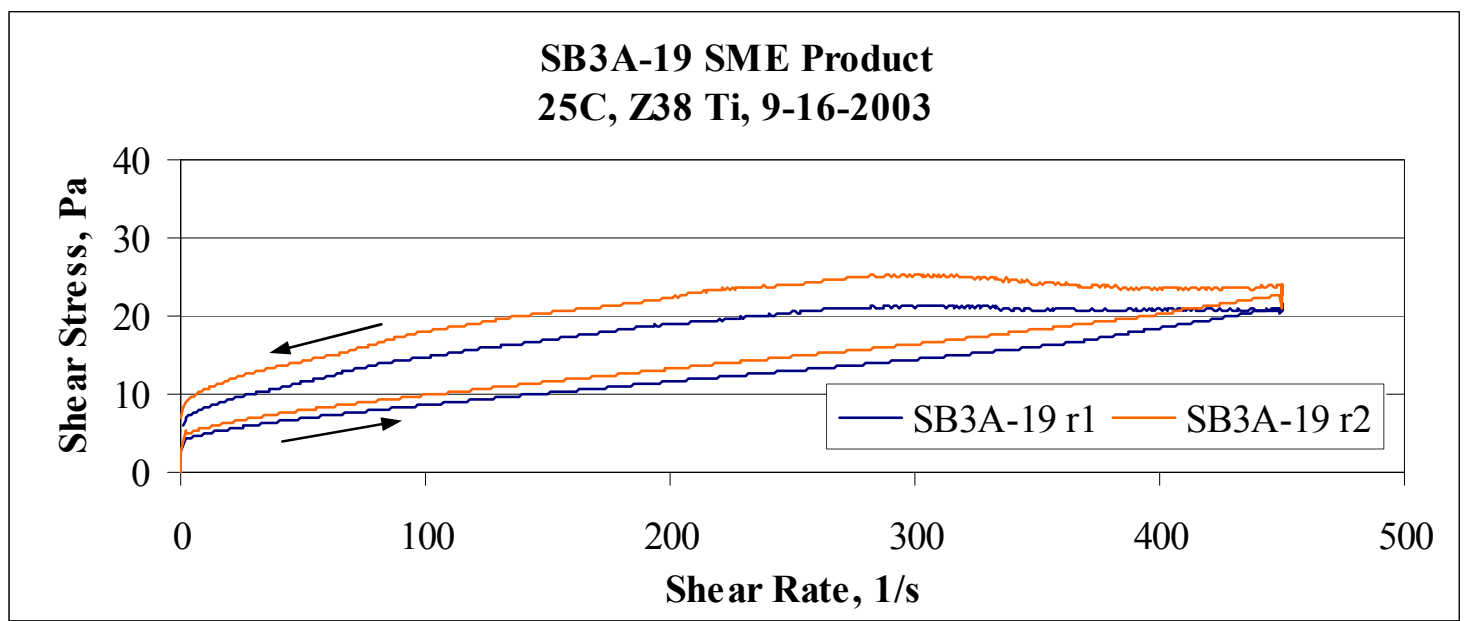

This is the raw flow curve data for SB3A-20.

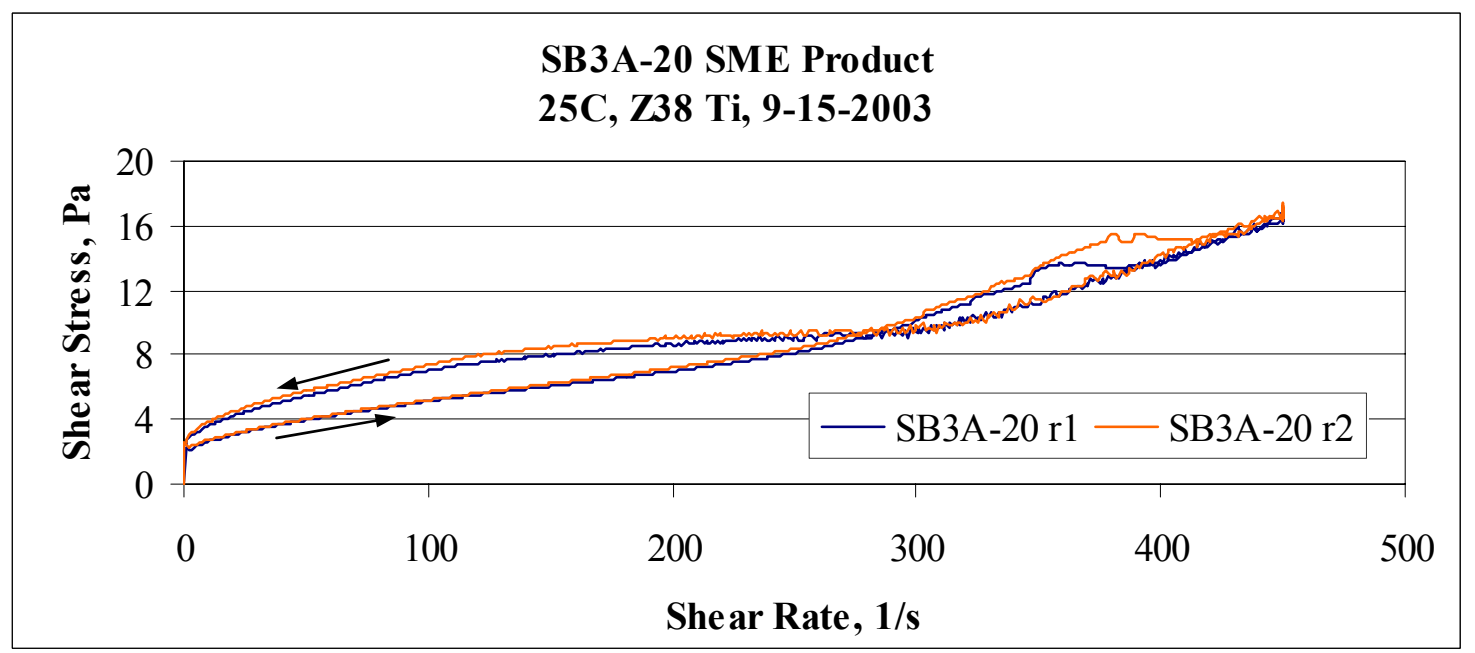


WSRC-TR-2004-00116

Revision 0

This page intentionally left blank. 
WSRC-TR-2004-00116

Revision 0

\section{APPENDIX B. Rheological Data for SB2/3 Samples}


This Appendix presents rheological data obtained at ACTL for blends of SB2 and SB3 waste simulants following SRAT or SME processing. Samples from the 22-L scale equipment are described first.

Case $6 \mathrm{~b}$ SME product for melt rate testing, 31\% waste loading, first SRAT/SME run:

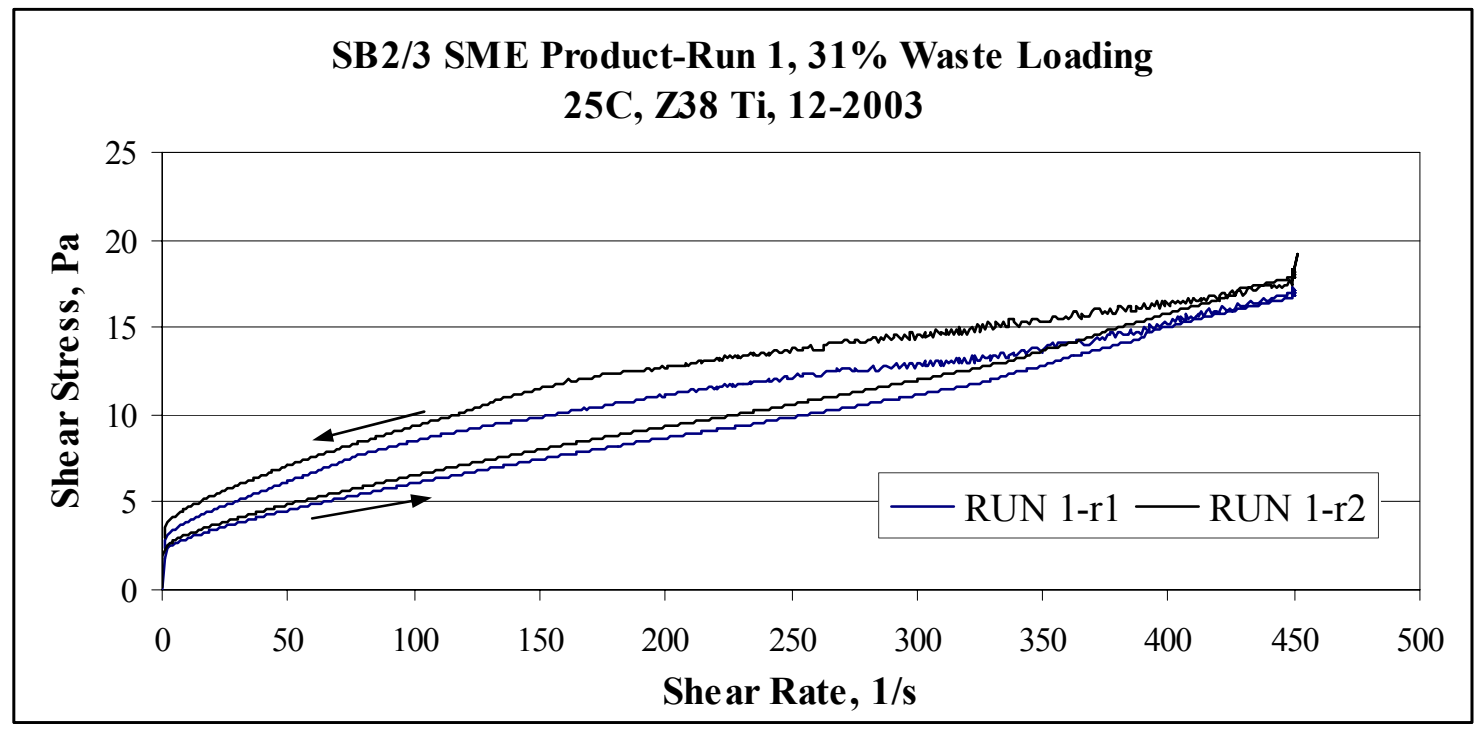

Case $6 \mathrm{~b}$ SME product for melt rate testing, 31\% waste loading, second SRAT/SME run:

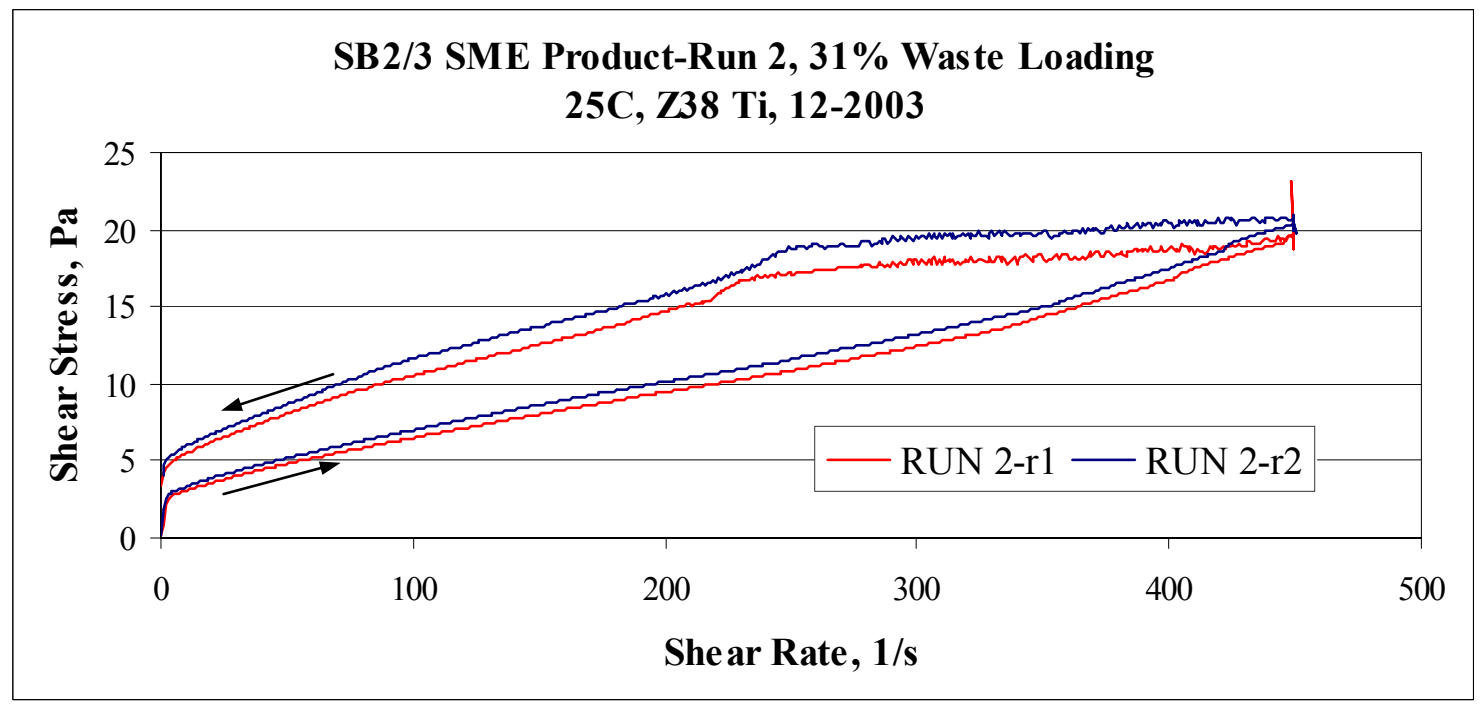

Reproducibility of the up ramp flow curves (lower portions) was very good both within the data from each sample and between the products from the two runs. This same reproducibility was observed in the $35 \%$ waste loading data below. 
Case $6 \mathrm{~b}$ SME product for melt rate testing, 35\% waste loading, first SRAT/SME run:

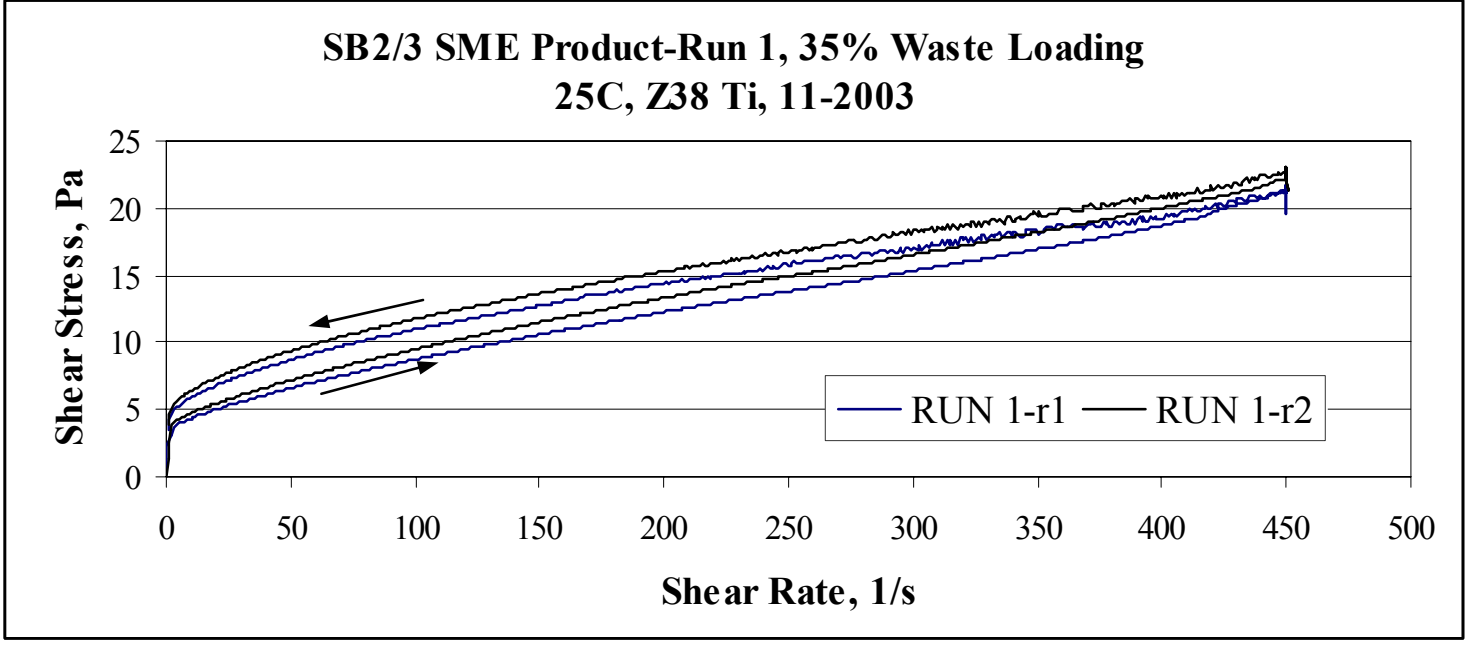

Case $6 \mathrm{~b}$ SME product for melt rate testing, 35\% waste loading, second SRAT/SME run:

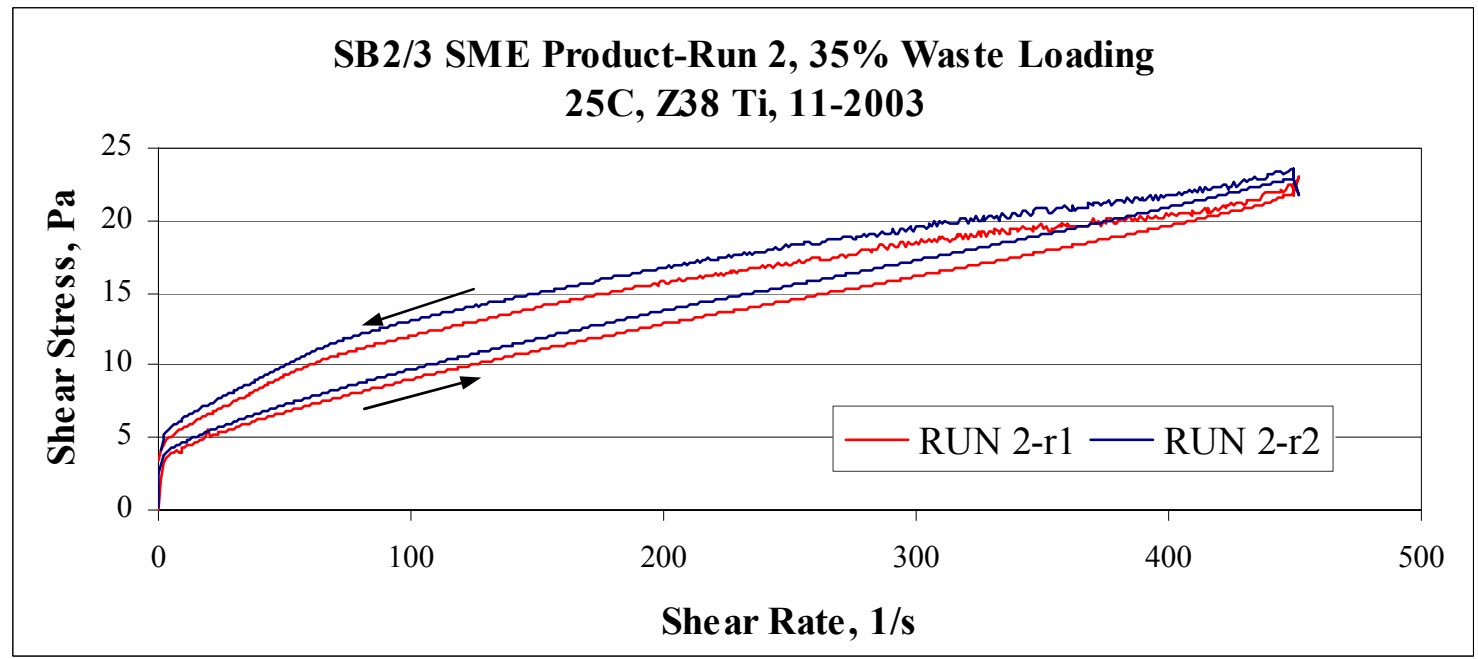

Case $6 \mathrm{~b}$ SME product for melt rate testing, 35\% waste loading, blend of first and second runs:

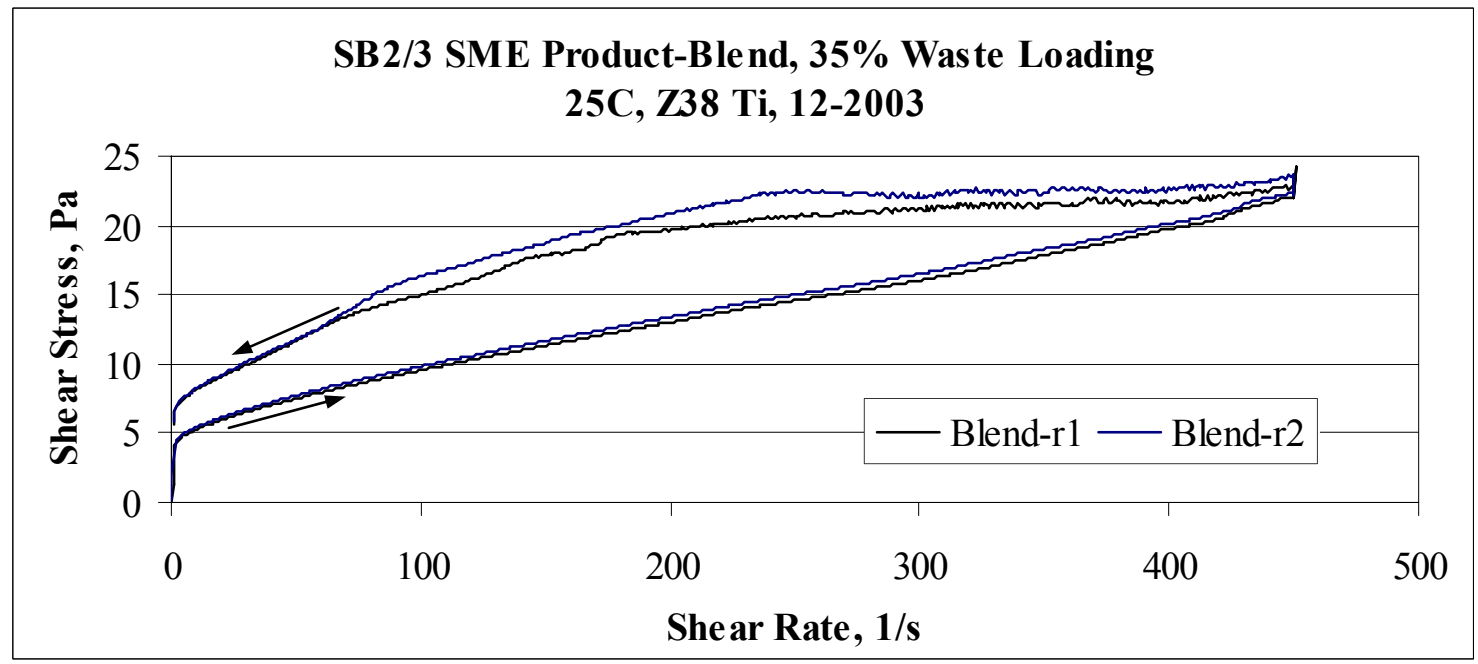


Case $6 \mathrm{~b}$ SME product for melt rate testing at $40 \%$ waste loading:

This sample was a blend of SRAT/SME Runs 2 and 3, which were two runs that used frit 202 in the SME cycle. SRAT acid addition was $135 \%$ of stoichiometry.

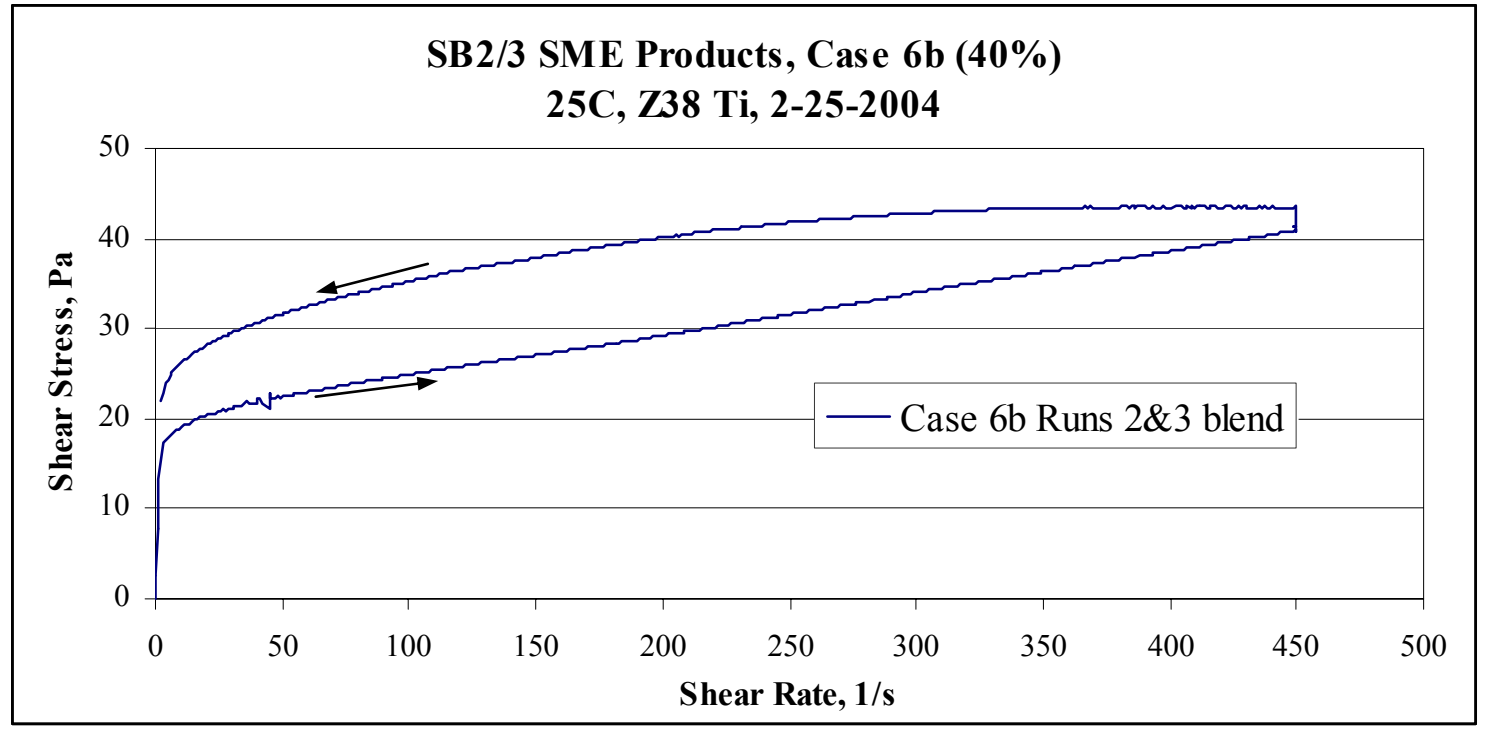

Case $7 \mathrm{~d}$ SME product for melt rate testing at $40 \%$ waste loading:

The sample from SRAT/SME Run 1 was analyzed like the SB2/3 acid addition flow sheet study SME products, and the sample from SRAT/SME Run 2 was analyzed like the Case 6b SME products in the melt rate study. These two runs used frit 418 in the SME cycle. SRAT acid addition was $135 \%$ of stoichiometry.

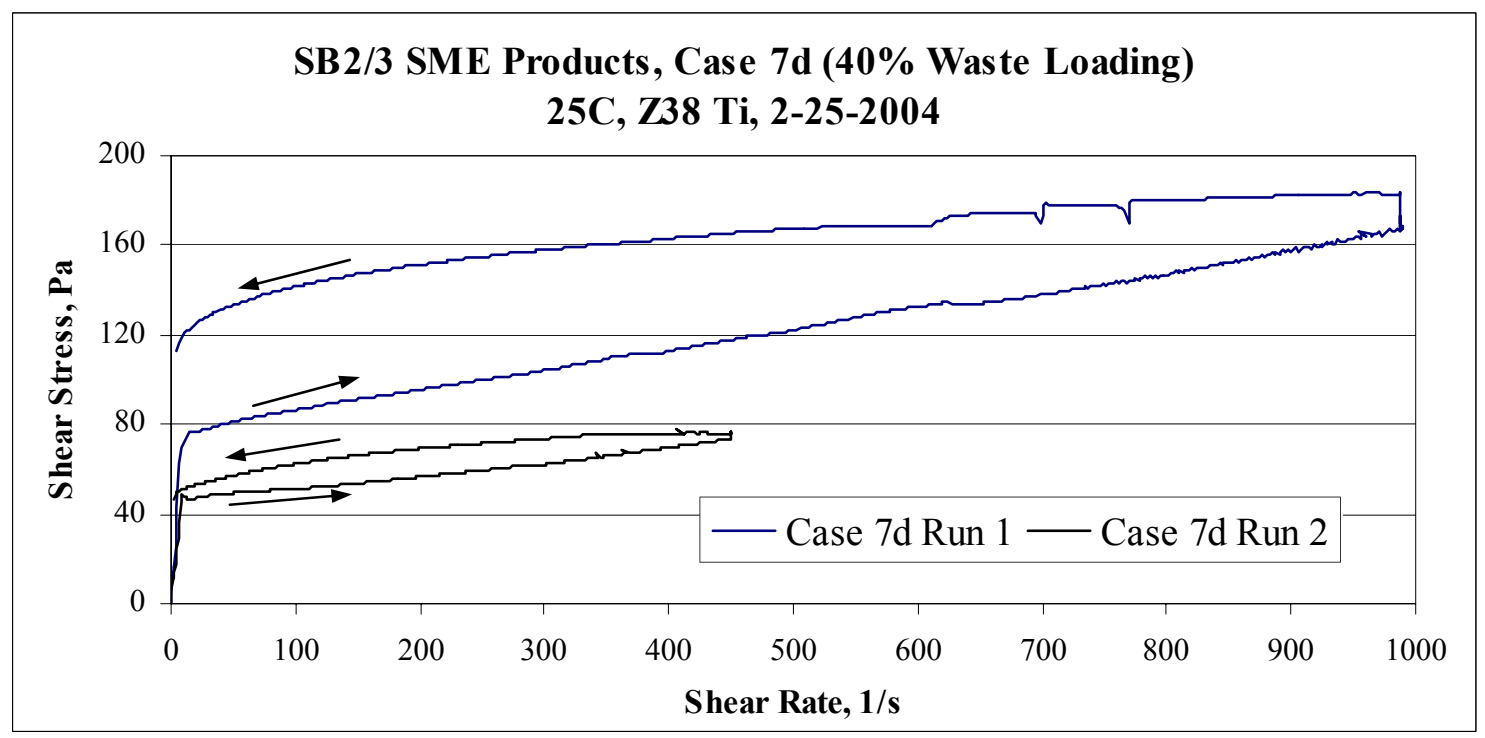

Run 2 SME product was slightly thinner visually than Run 1 SME product. The difference in the plots indicates a real difference, and is not an artifact of the rheological measuring method. This could be due to the how the batches were prepared. 


\section{4-L scale SB2/3 Acid Addition Study:}

Raw SB2/3 Case 6b SRAT product rheology data at 140\% acid:

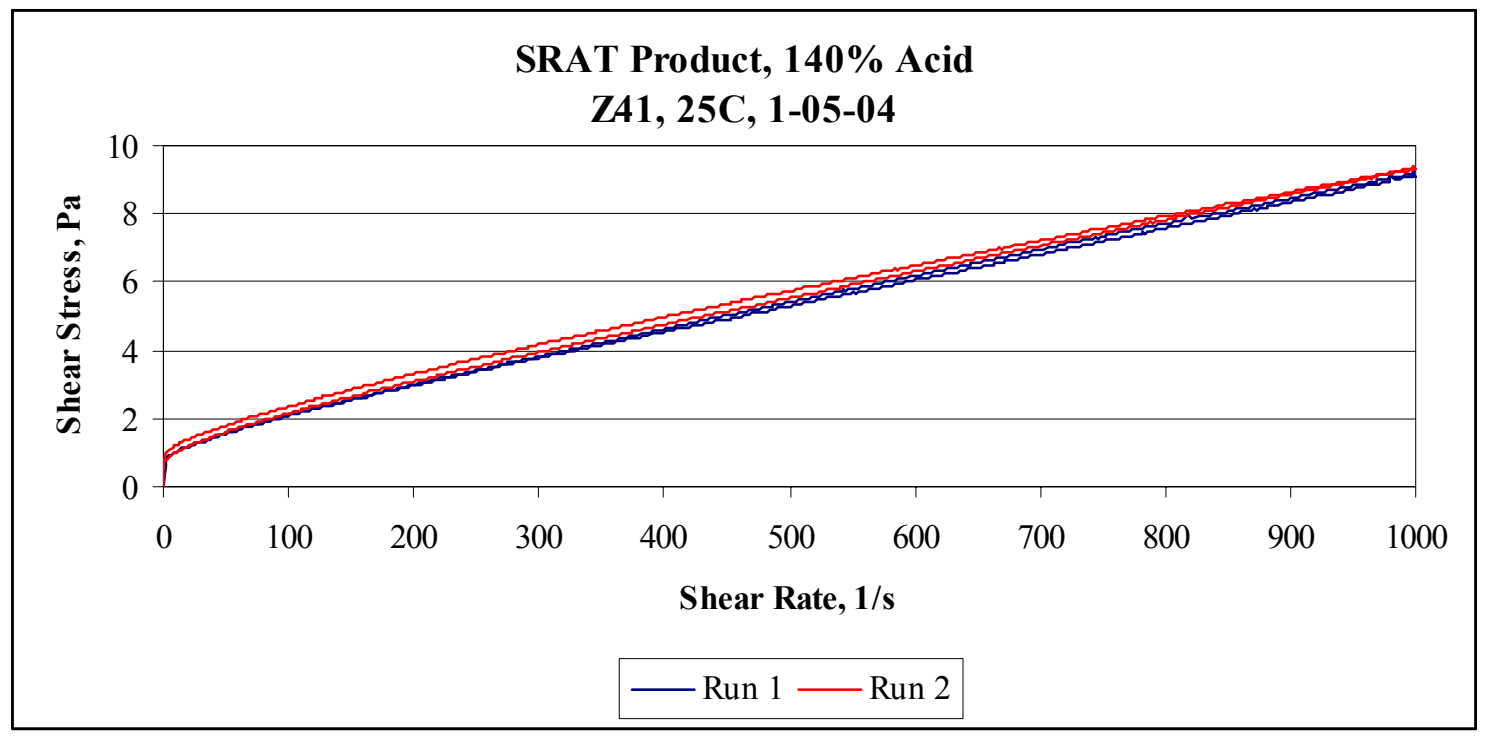

Raw SB2/3 Case 6b SRAT product rheology data at 155\% acid:

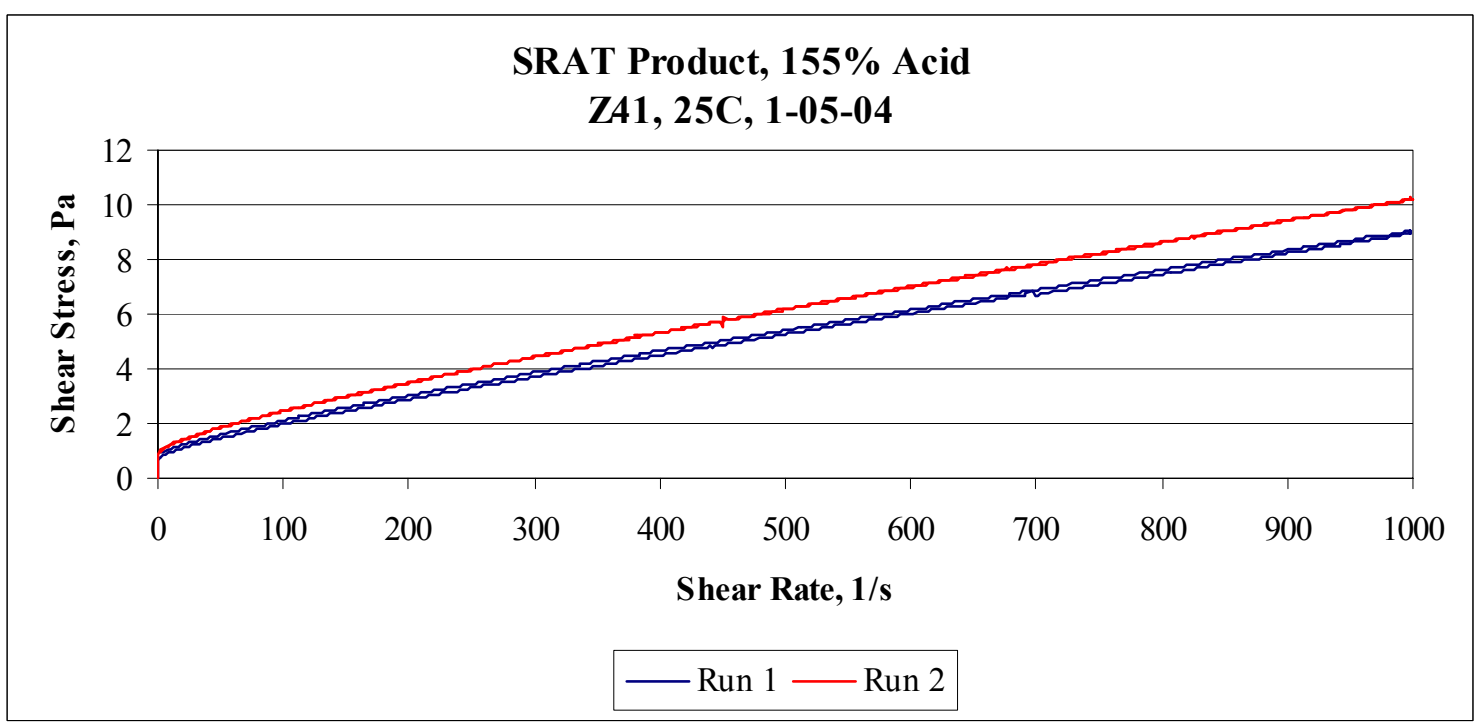


Raw SB2/3 Case 6b SRAT product rheology data at 170\% acid:

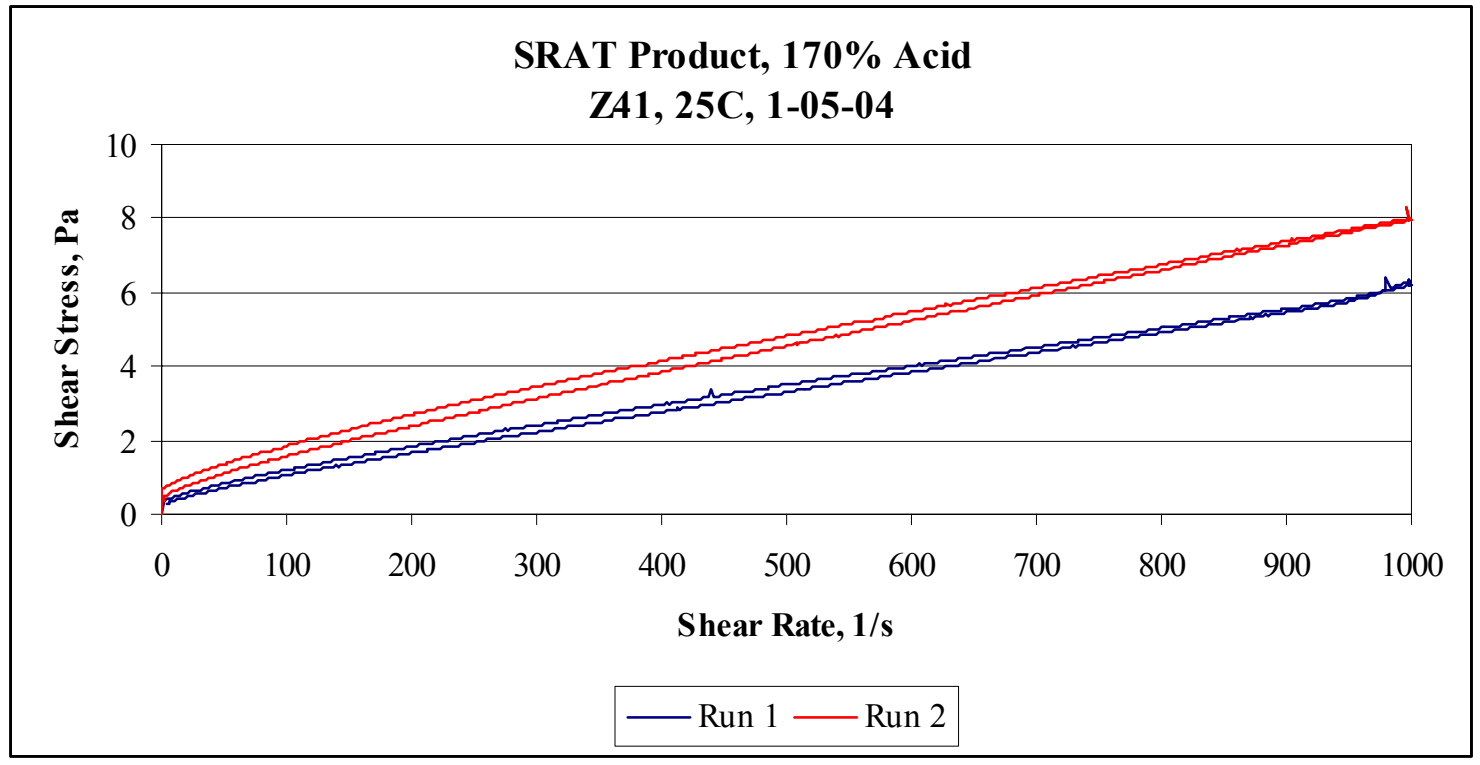

Raw SB2/3 Case 6 b SRAT product rheology data at $185 \%$ acid:

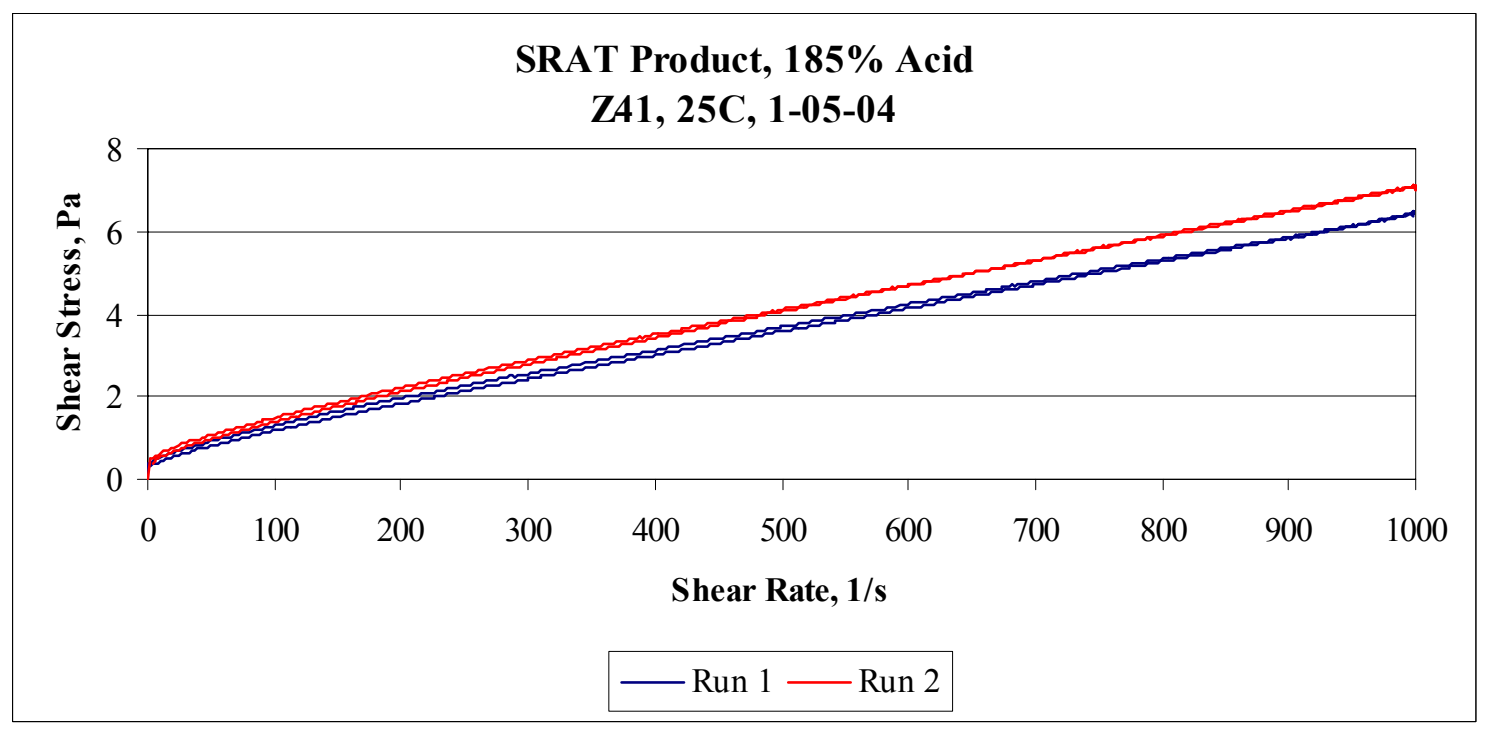


Viscosity Data for 140\% Case 6b SME product supernate (before formic acid dump):

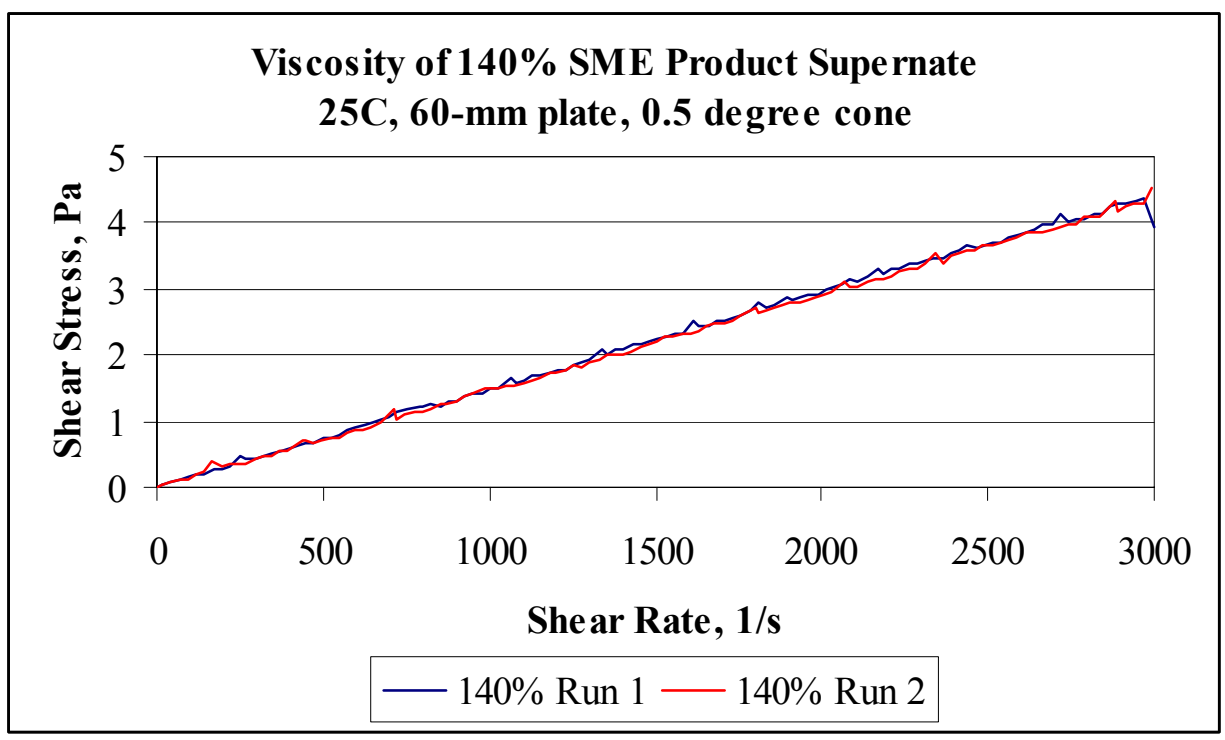

Data give 1.46 and $1.48 \mathrm{cP}$ for the two curves.

Viscosity Data for 185\% Case 6b SME product supernate (before formic acid dump):

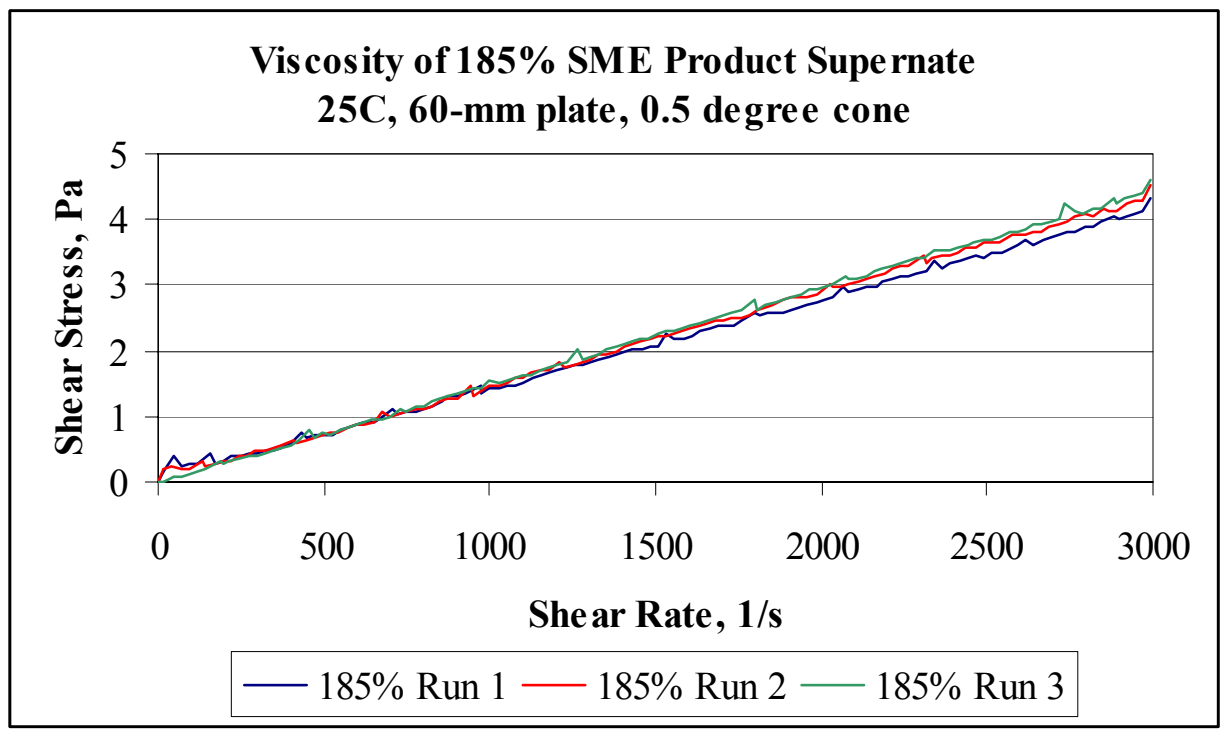

Data give $1.40,1.45$, and $1.49 \mathrm{cP}$ for the three curves. 
Run 1 data for SB2/3 acid addition flow sheet study SME products following the formic acid dump (second runs given in main body).

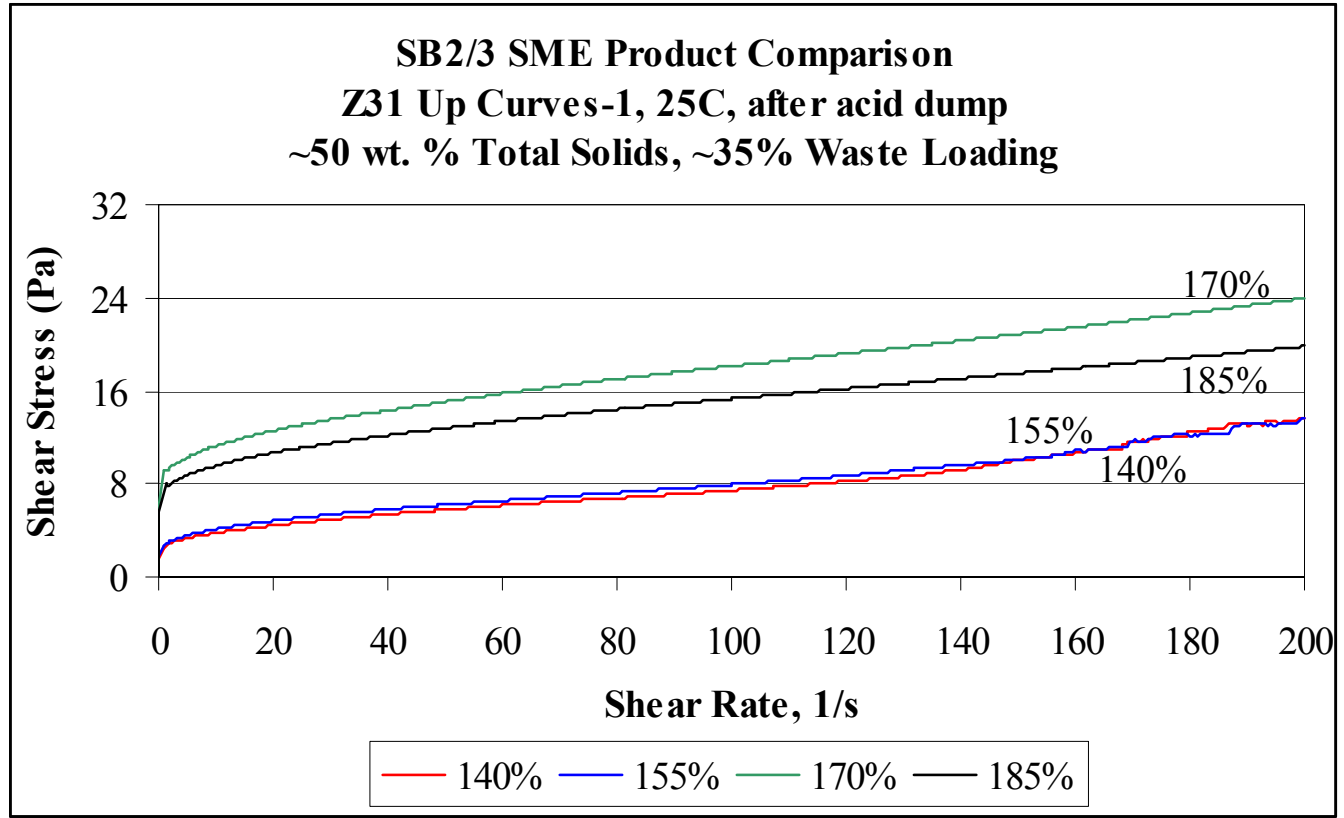

Raw SME product (prior to formic acid dump) from the 155\% run showing predicted onset of Taylor vortices at about 600/s shear rate during the up ramp (second run similar).

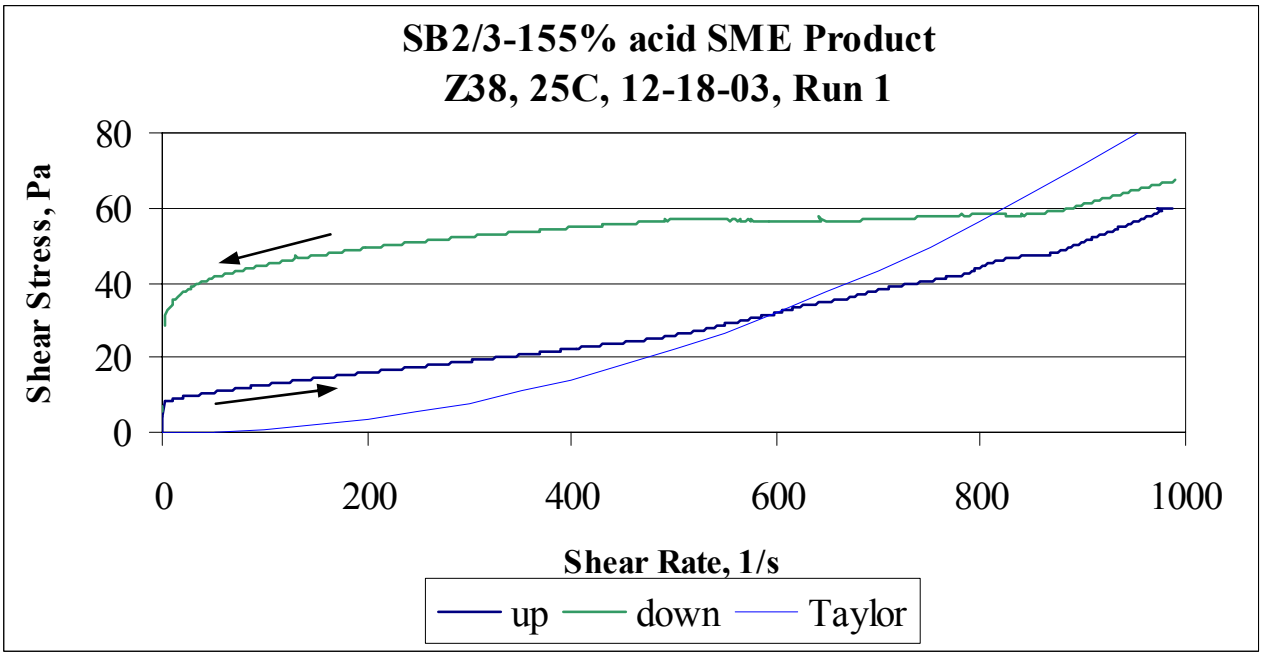


Raw SME product (prior to formic acid dump) from the 155\% run showing predicted onset of Taylor vortices at about 165/s shear rate during the up ramp (second run similar).

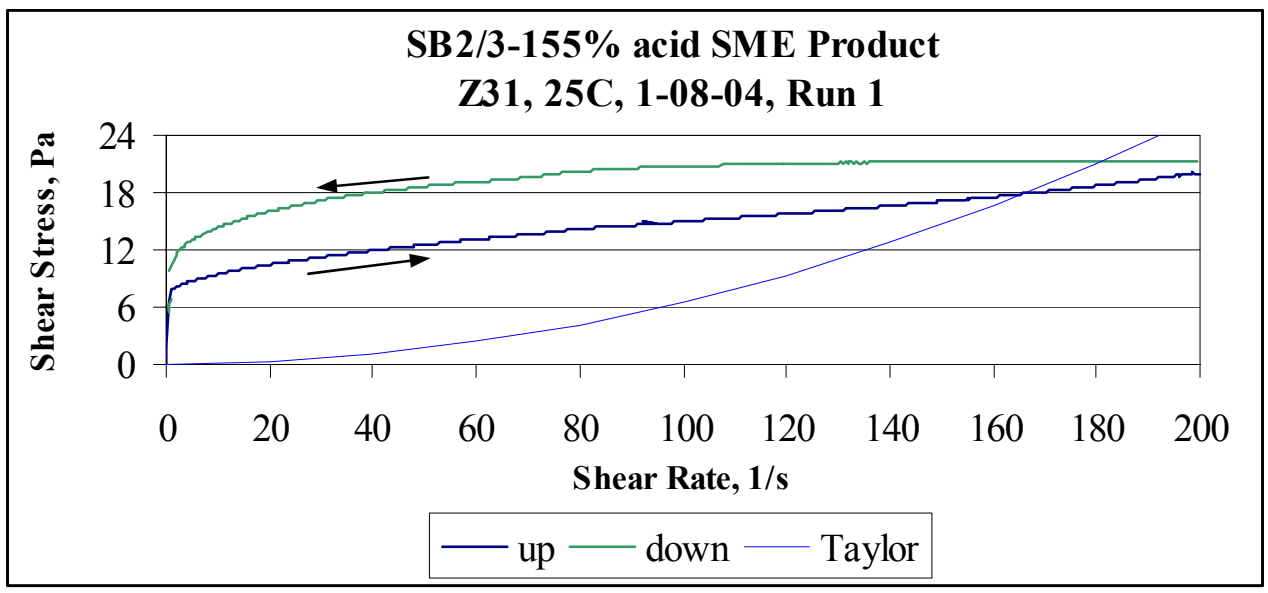

The Taylor vortices are produced at lower shear rates when using the Z31 bob than when using the Z38 bob. The reason is that as the annular gap increases, the onset of Taylor vortices occurs at a lower shear rate. The Z31 has a larger gap than that of the Z38 bob. Data below the Taylor vortices curve can not be used for analysis.

Z38 and Z31 data for the other three acid additions were generally similar with respect to the onset of Taylor vortices.

The next two plots give comparisons of the effect of the formic acid dump on the SB2/3 SME products from the runs at $140 \%$ and $170 \%$ acid (the $155 \%$ and $185 \%$ data are in the main body of the report.)

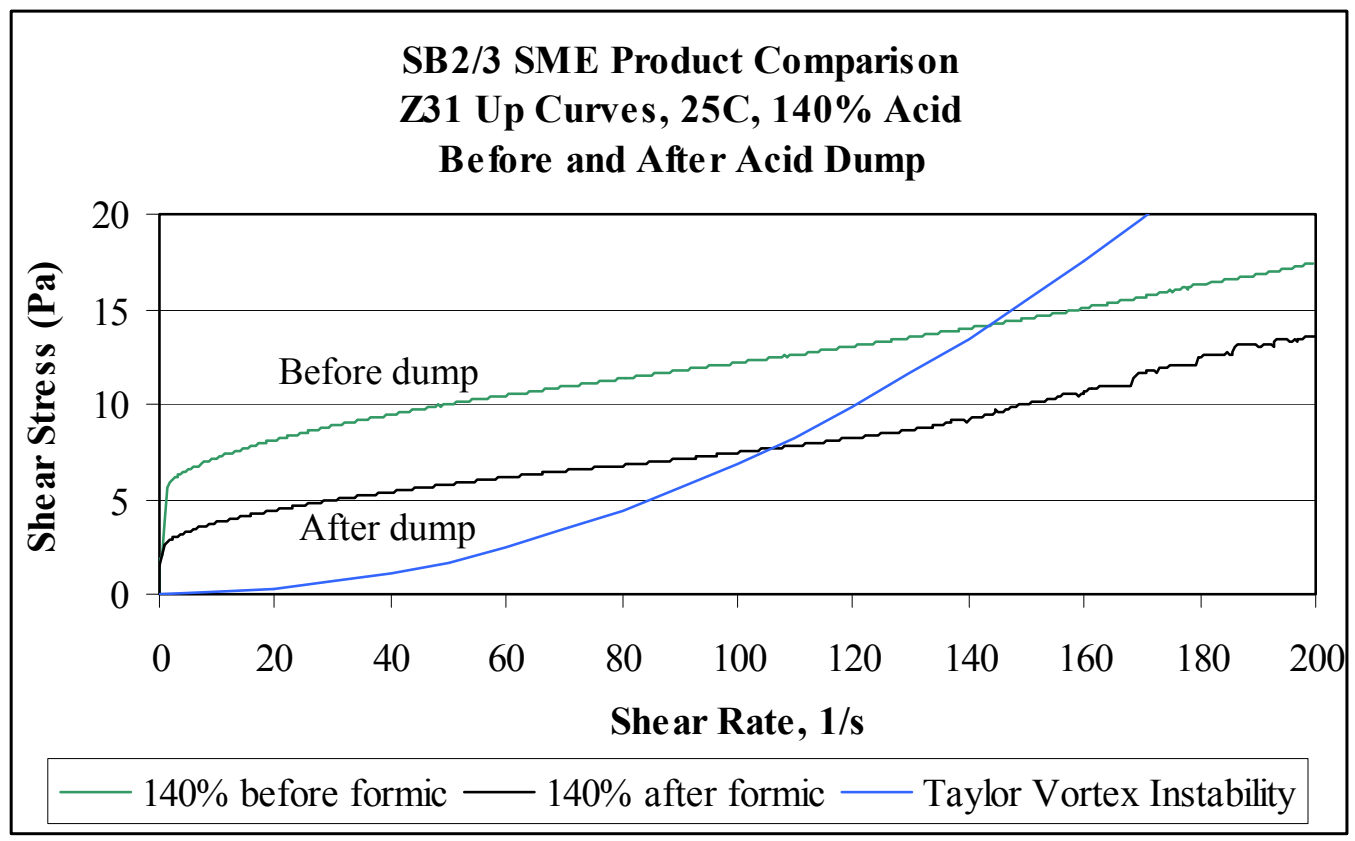


WSRC-TR-2004-00116

Revision 0

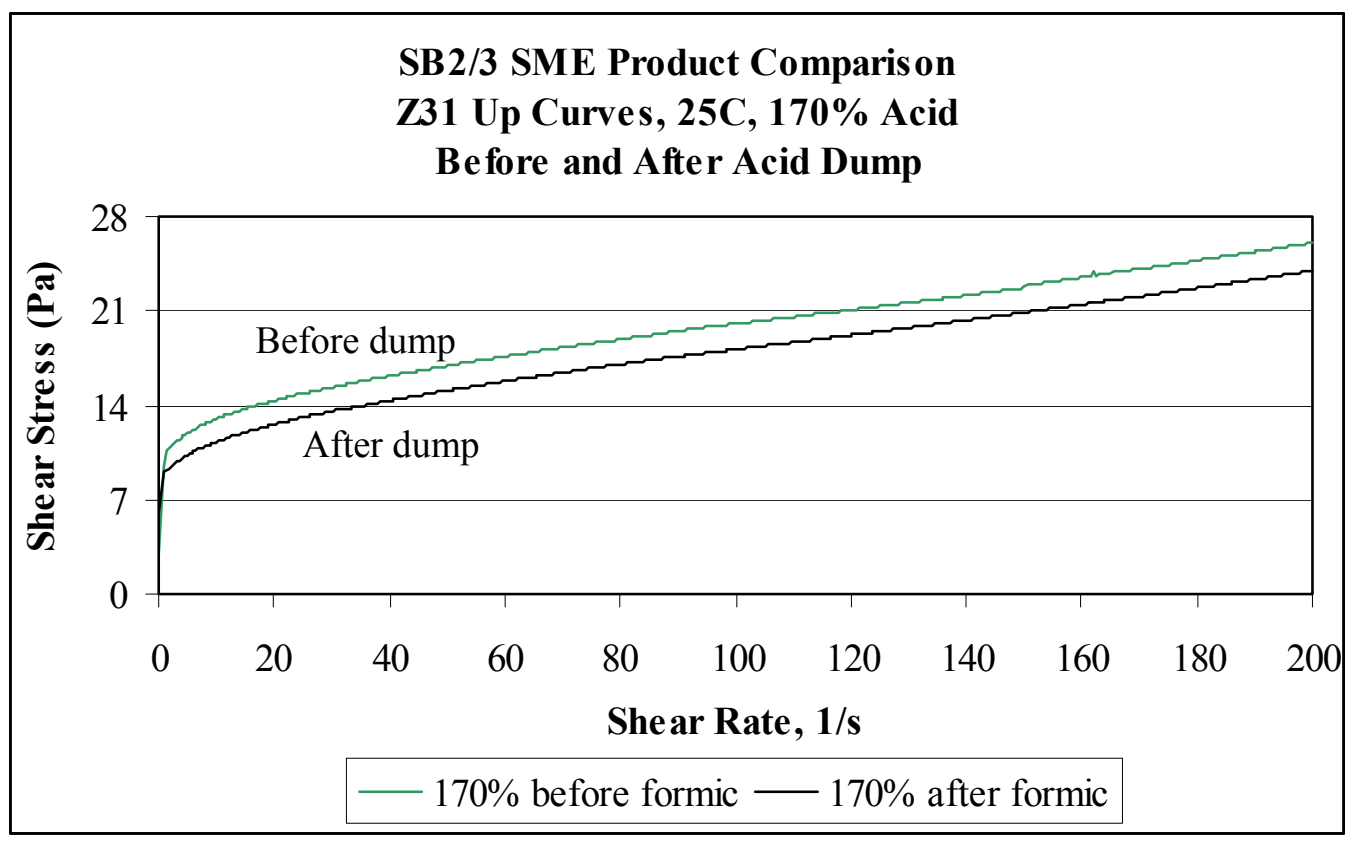

The relative impact of the formic acid dump in thinning the SME products appeared to become less significant as the original SME product samples became more viscous. At $170 \%$, the dump produced a 2$3 \mathrm{~Pa}$ decrease in shear stress requirements. At 140\% the dump also produced about a $3 \mathrm{~Pa}$ decrease in shear stress requirements. The $170 \%$ acid SME product was roughly twice as viscous as the $140 \%$ product to begin with, so the relative impact of the formic acid dump was only about half as much. 